Prepared for the U.S. Department of Energy

Under Contract DE-AC05-76RL01830

\title{
Tier II Analysis of Vadose Zone Sediments from UPRS 200-E-81 and 200-E-86
}

\author{
MM Valenta \\ KN Geiszler \\ BN Bjornstad \\ HT Schaef \\ CF Brown
}

April 2009 


\title{
DISCLAIMER
}

This report was prepared as an account of work sponsored by an agency of the United States Government. Neither the United States Government nor any agency thereof, nor Battelle Memorial Institute, nor any of their employees, makes any warranty, express or implied, or assumes any legal liability or responsibility for the accuracy, completeness, or usefulness of any information, apparatus, product, or process disclosed, or represents that its use would not infringe privately owned rights. Reference herein to any specific commercial product, process, or service by trade name, trademark, manufacturer, or otherwise does not necessarily constitute or imply its endorsement, recommendation, or favoring by the United States Government or any agency thereof, or Battelle Memorial Institute. The views and opinions of authors expressed herein do not necessarily state or reflect those of the United States Government or any agency thereof.

\author{
PACIFIC NORTHWEST NATIONAL LABORATORY \\ operated by \\ BATTELLE \\ for the \\ UNITED STATES DEPARTMENT OF ENERGY \\ under Contract DE-AC05-76RL01830
}

Printed in the United States of America

Available to DOE and DOE contractors from the

Office of Scientific and Technical Information,

P.O. Box 62, Oak Ridge, TN 37831-0062;

ph: (865) 576-8401

fax: $(865) 576-5728$

email: reports@adonis.osti.gov

\footnotetext{
Available to the public from the National Technical Information Service, U.S. Department of Commerce, 5285 Port Royal Rd., Springfield, VA 22161 ph: (800) 553-6847 fax: $(703) 605-6900$

email: orders@ntis.fedworld.gov

online ordering: http://www.ntis.gov/ordering.htm
}

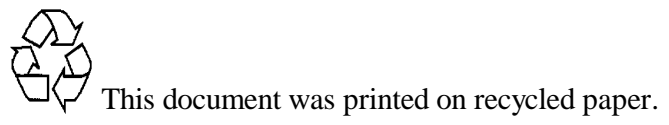




\title{
Tier II Analysis of Vadose Zone Sediments from UPRS 200-E-81 and 200-E-86
}

\author{
MM Valenta \\ KN Geiszler \\ BN Bjornstad \\ HT Schaef \\ CF Brown
}

April 2009

Prepared for

the U.S. Department of Energy

under Contract DE-AC05-76RL01830

Pacific Northwest National Laboratory

Richland, Washington 99352 



\section{Contents}

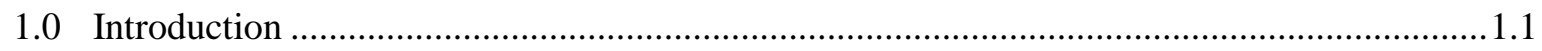

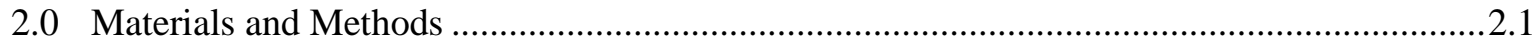

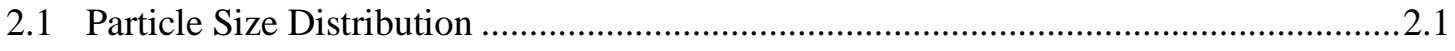

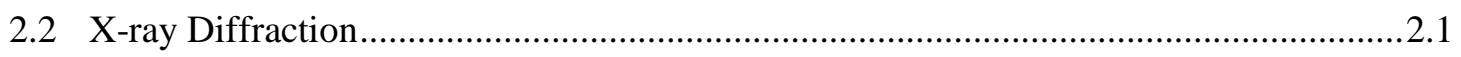

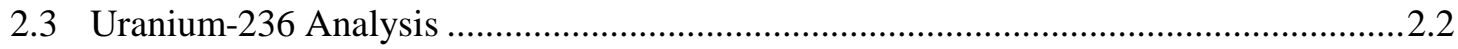

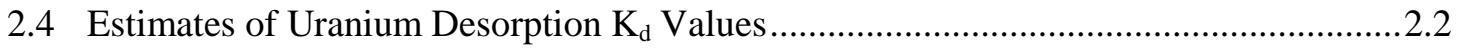

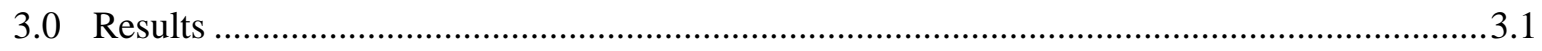

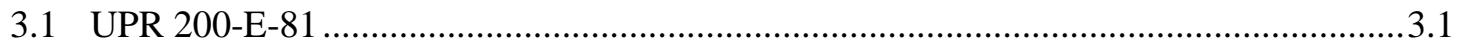

3.1.1 Particle Size Analysis...................................................................................

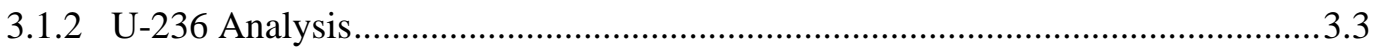

3.1.3 Uranium Desorption $\mathrm{K}_{\mathrm{d}}$ Estimates .................................................................3.3

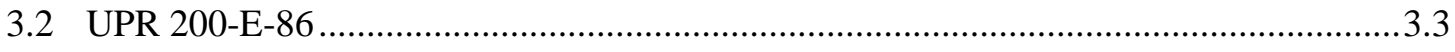

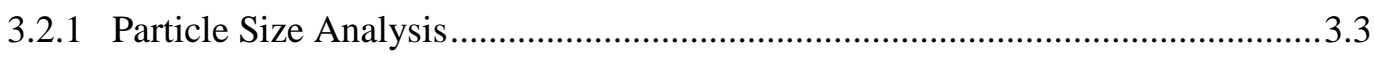

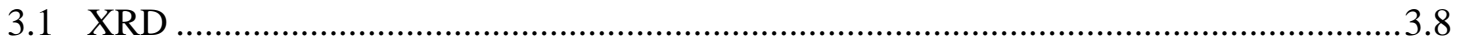

3.2 241-C Tank Farm Paleosol Geology ……….....................................................................

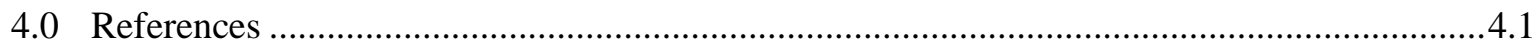

5.0 Appendix A - Bulk Powder XRD Scans............................................................................ 5.1

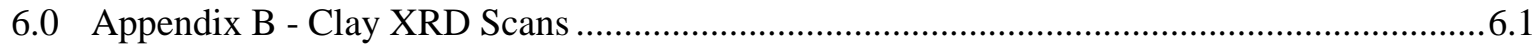




\section{Figures}

Figure 1. Graph of hydrometer and sieving results for sample B1VJ58C ....................................3.2

Figure 2. Graph of hydrometer and sieving results for sample B1VJ62C .......................................2

Figure 3. Graph of hydrometer and sieving results for sample B1RTH3C.................................... 3.5

Figure 4. Graph of hydrometer and sieving results for sample B1RYR8C ................................... 3.5

Figure 5. Graph of hydrometer and sieving results for sample B1T2P2C.....................................6

Figure 6. Graph of hydrometer and sieving results for sample B1T2P5C.....................................6

Figure 7. Graph of hydrometer and sieving results for sample B1T2R0C …................................. 3.7

Figure 8. Graph of hydrometer and sieving results for sample B1TNK8C ...................................

Figure 9. Bulk powder XRD tracings of randomly oriented specimen from sample B1VJ58C.....3.8

Figure 10. XRD tracings of preferentially oriented $<2.0 \mu \mathrm{m}$ fraction (B1TNK8C) ......................3.9

Figure 11. Wells in vicinity of IDF where presence of paleosols were evaluated (Reidel 2005)...3.11 


\section{Tables}

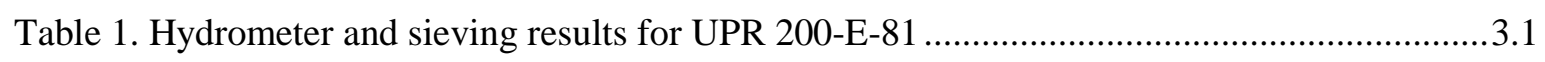

Table 2. U-235, U-236 and U-238 results (in counts per second) for sample B1VJ58A ................3.3

Table 3. Estimated Uranium $\mathrm{K}_{\mathrm{d}}(\mathrm{ml} / \mathrm{g})$ desorption values ........................................................3.3

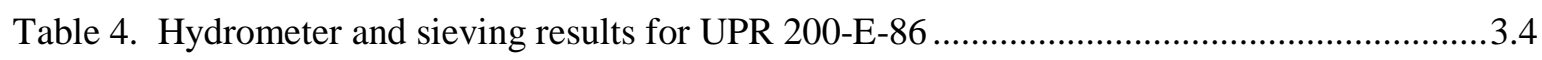




\subsection{Introduction}

The overall goals of the Tank Farm Vadose Zone Project, led by Washington River Protection Solutions, are to define risks from past and future single-shell tank farm activities; identify and evaluate the efficacy of interim measures; and aid, via collection of geochemical information and data, the future decisions that must be made by the U.S. Department of Energy (DOE) regarding the near-term operations, future waste retrieval, and final closure activities for the single-shell tank waste management areas (WMAs). To meet the investigative goals of the Tank Farm Vadose Zone Project, the Environmental Sciences Laboratory performed geochemical analyses on vadose zone sediments collected within Waste Management Area C. Tier one analyses of UPR-200-E-86, which includes direct push probe holes C5952, C5958 and C5960, were performed between 3/25/08 and 4/14/08. Preliminary results were presented to CH2M Hill Hanford Group on 6/5/08. As a result of the tier one investigations, further tier two analyses were requested. Tier two investigations include particle size and mineralogy analyses on samples collected between 80 to 120 feet below ground surface that were found to contain high concentrations of chloride and sulfate.

Tier one analyses on sediments retrieved near UPR-200-E-81, direct push probe hole C6394, were performed between $6 / 20 / 08$ and $7 / 22 / 08$. Preliminary results of the tier one analyses were presented on $8 / 15 / 08$. As a result of the tier one investigations, further tier two analyses were requested. Tier two analyses include determining whether U-236 exists in samples at approximately 42 feet below the ground surface. Confirmation of U-236 will determine whether the U-238 seen in the leaches performed on samples at that depth is a result of contamination and not from leaching natural uranium. Using the water and acid extract $\mathrm{U}-238$ concentrations from the tier one analysis, equilibrium $\mathrm{Kd}$ values were requested to be calculated. Additional tier two analysis includes particle size analysis on samples collected at approximately 135 feet below ground surface to investigate a moist layer containing high chloride and sulfate anion concentrations. Particle size analysis was also requested for a sample collected at approximately 42 feet below ground surface due to its high moisture content and nitrate concentrations. The ESL was also requested to examine Paleosols to determine where the paleosols from the Integrated Disposal Facility would extrapolate to in WMA C.

This data report captures the results of the requested Tier two analyses associated with UPRs 200-E81 and 200-E-86. It is anticipated that this information will be combined with Tier one data to create a comprehensive interpretive report once sufficient funding becomes available. 


\subsection{Materials and Methods}

This chapter discusses the methods and philosophy used to characterize the UPR 200-E-81 and UPR 200-E-86 direct-push samples and the parameters that were measured and analyzed in the laboratory. It also describes the materials and methods used to conduct analyses of the physical, geochemical, and radio-analytical properties of the sediments.

\subsection{Particle Size Distribution}

A combination of dry sieving and the hydrometer method was used to determine the particle size distribution of the selected samples from UPR 200-E-81 and UPR 200-E-86. The dry sieving technique is described in ASTM D6913, "Standard Test Methods for Particle-Size Distribution (Gradation) of Soils Using Sieve Analysis”. The hydrometer procedure is described in ASA (1986a), Part 1, Method 15-5, "Hydrometer Method". The clay separates were saved from the hydrometer experiment for subsequent mineralogical analyses. The samples were air-dried prior to performing the hydrometer and dry sieving methods.

The particle density of the samples is an input needed for some of the calculations when using the hydrometer method. However, no direct particle density measurements were made for the sediments from UPR 200-E-81 and UPR-200-E-86. The particle size data reported used the quartz default value of $2.65 \mathrm{~g} / \mathrm{cm} 3$ to calculate the particle size distribution. The error in using this assumption is not significant, particularly since most of the samples consisted of fine to coarse-grained sand.

\subsection{X-ray Diffraction}

Mineralogy of the whole rock $(<2 \mathrm{~mm})$ and clay-size fractions ( $<2$ micron) was determined by $\mathrm{x}$-ray diffraction (XRD) techniques. Bulk samples were prepared by crushing one gram of homogenized samples in an agate mortar and pestle before packing into aluminum sample holders. Each specimen was analyzed using a Scintag XRD unit equipped with a Peltier thermoelectrically cooled detector and a copper x-ray tube. Individual scans were obtained from 2 to $65^{\circ} 2 \theta\left(0.02^{\circ}\right.$ step $)$ with a dwell time of 2 seconds. Scans were collected electronically and processed using the JADE® XRD pattern processing software. Identification of the mineral phases was based on mineral powder diffraction files (PDFTM) published by the Joint Committee on Powder Diffraction Standards (JCPDS) International Center for Diffraction Data (ICDD) (Newtown Square, Pennsylvania).

Preparation of the clay fraction for XRD analysis began by dispersing the whole rock sediment. Approximately $100 \mathrm{~g}$ of sediment was transferred into a $1.0 \mathrm{~L}$ bottle and mixed with $1.0 \mathrm{~L}$ of $0.001 \mathrm{M}$ sodium hexametaphosphate. The suspensions were allowed to shake over night to ensure complete dispersion. The sand and silt fractions were separated from the clay fractions by using Stoke's Law of settling. The lower limit of the silt fraction was taken at $>1.4 \mu \mathrm{m}$. Each clay suspension was concentrated to an approximate volume of $30 \mathrm{ml}$ by adding a few drops of $10 \mathrm{~N} \mathrm{MgCl}_{2}$ to the dispersed slurry after silt removal. Concentrations of the clay in the concentrated suspensions were determined by drying known volumes of the suspension and weighing the dried sample. The density of the slurry was calculated from the volume pipetted and the final weight of dried sample. Volumes of slurry equaling $250 \mathrm{mg}$ of clay were transferred into centrifuge tubes and saturated with either $\mathrm{Mg}^{2+}$ or $\mathrm{K}^{1+}$ cations. Clay 
samples were prepared using the Drever (1973) method and placed onto an aluminum slide for XRD analysis. Due to the tendency of the clay film to curl and peel off the slide, the $\mathrm{Mg}^{2+}$ saturated specimens were immediately solvated with a few drops of a $10 \%$ solution of ethylene glycol in ethanol and placed into a dessiccator containing excess ethylene glycol for a minimum of 24 hours.

Slides of preferentially oriented clay were scanned from 2 to $45^{\circ} 2 \theta$ with a dwell time of 2 seconds. Scans were collected electronically and processed as described earlier for the bulk powdered samples.

\subsection{Uranium-236 Analysis}

Direct Analysis of ${ }^{236} \mathrm{U}$ was performed via ICP-MS following PNNL-AGG-415 (Clayton 2008). All solution samples were analyzed using a Perkin Elmer ELAN DRC II ICP-MS (Shelton, CT) equipped with a dual-channel gas manifold. Plasma power was set to 1500 watts, with a plasma gas flow of 18 $\mathrm{ml} / \mathrm{min}$ and an auxiliary gas flow of $1.225 \mathrm{ml} / \mathrm{min}$. A low-flow PFA-100 Teflon nebulizer with a gas flow of $1.08 \mathrm{ml} / \mathrm{min}$ was used for sample introduction. The Perkin Elmer DRC II uses a PC3 Peltier cooled cyclonic spray chamber. For ICP-MS, high-purity calibration standards were used to generate calibration curves, and to verify continuing calibration during the analysis. Dilutions of 10 times for water extracts and 50 times for acid extracts were made for each sample and analyzed to investigate and correct for matrix interferences.

\subsection{Estimates of Uranium Desorption $\mathrm{K}_{\mathrm{d}}$ Values}

By combining the uranium data from the dilution-corrected 1:1 water extractions with the uranium concentrations measured in the acid leaches, an estimate of the desorption $K_{d}$ values for uranium were made. To determine the amount of uranium that would remain on the solid at equilibrium with the pore fluid, the amount of uranium present in the pore water (obtained from the 1:1 water extract) is subtracted from the total concentration of uranium present in the sediment sample (obtained from the acid leaches). The desorption $\mathrm{K}_{\mathrm{d}}(\mathrm{mL} / \mathrm{g})$ is calculated by dividing the uranium remaining on the solid at equilibrium (mass per gram of sediment) by the pore-water concentration (mass per $\mathrm{mL}$ ). 


\subsection{Results}

This section presents the Tier II geochemical and physical characterization data collected on sediment from the direct-push holes emplaced near UPRs 200-E-81 and 200-E-86. The primary goals of these tests were to provide supplemental characterization data to the Tier I tests and to form the basis on which the nature and extent of mobile contaminants in the vadose zone sediments could be determined.

\subsection{UPR 200-E-81}

\subsubsection{Particle Size Analysis}

Table 1. Hydrometer and sieving results for UPR 200-E-81

\begin{tabular}{|c|c|c|c|}
\hline \multicolumn{2}{|c|}{ B1VJ58C } & \multicolumn{2}{|c|}{ B1VJ62C } \\
\hline $\begin{array}{c}\text { Diameter } \\
(\mu \mathrm{m})\end{array}$ & $\begin{array}{c}\% \% \\
\text { finer than }\end{array}$ & $\begin{array}{c}\text { Diameter } \\
(\mu \mathrm{m})\end{array}$ & $\begin{array}{c}\% \% \\
\text { finer than }\end{array}$ \\
\hline \multicolumn{4}{|c|}{ Dry Sieve } \\
\hline 63000 & 100 & 63000 & 100 \\
\hline 31500 & 100 & 31500 & 100 \\
\hline 16000 & 100 & 16000 & 100 \\
\hline 8000 & 92.7 & 8000 & 100 \\
\hline 4000 & 89.6 & 4000 & 100 \\
\hline 2000 & 84.9 & 2000 & 99.7 \\
\hline 1000 & 74.2 & 1000 & 83.5 \\
\hline 500 & 60.6 & 500 & 40.9 \\
\hline 250 & 46.7 & 250 & 23.7 \\
\hline 125 & 31.7 & 125 & 14.7 \\
\hline 63 & 16.7 & 63 & 8.48 \\
\hline \multicolumn{4}{|c|}{ Hydrometer } \\
\hline 83.5 & 23.7 & 81.5 & 10.7 \\
\hline 58.4 & 18.8 & 57.4 & 9.03 \\
\hline 33.3 & 12.8 & 32.9 & 6.57 \\
\hline 18.1 & 8.88 & 18.0 & 6.57 \\
\hline 10.4 & 6.91 & 10.4 & 4.92 \\
\hline 7.31 & 4.93 & 7.31 & 4.10 \\
\hline 5.95 & 3.95 & 5.95 & 3.28 \\
\hline 5.16 & 3.95 & 5.13 & 1.64 \\
\hline 1.49 & 3.95 & 1.48 & 1.64 \\
\hline
\end{tabular}




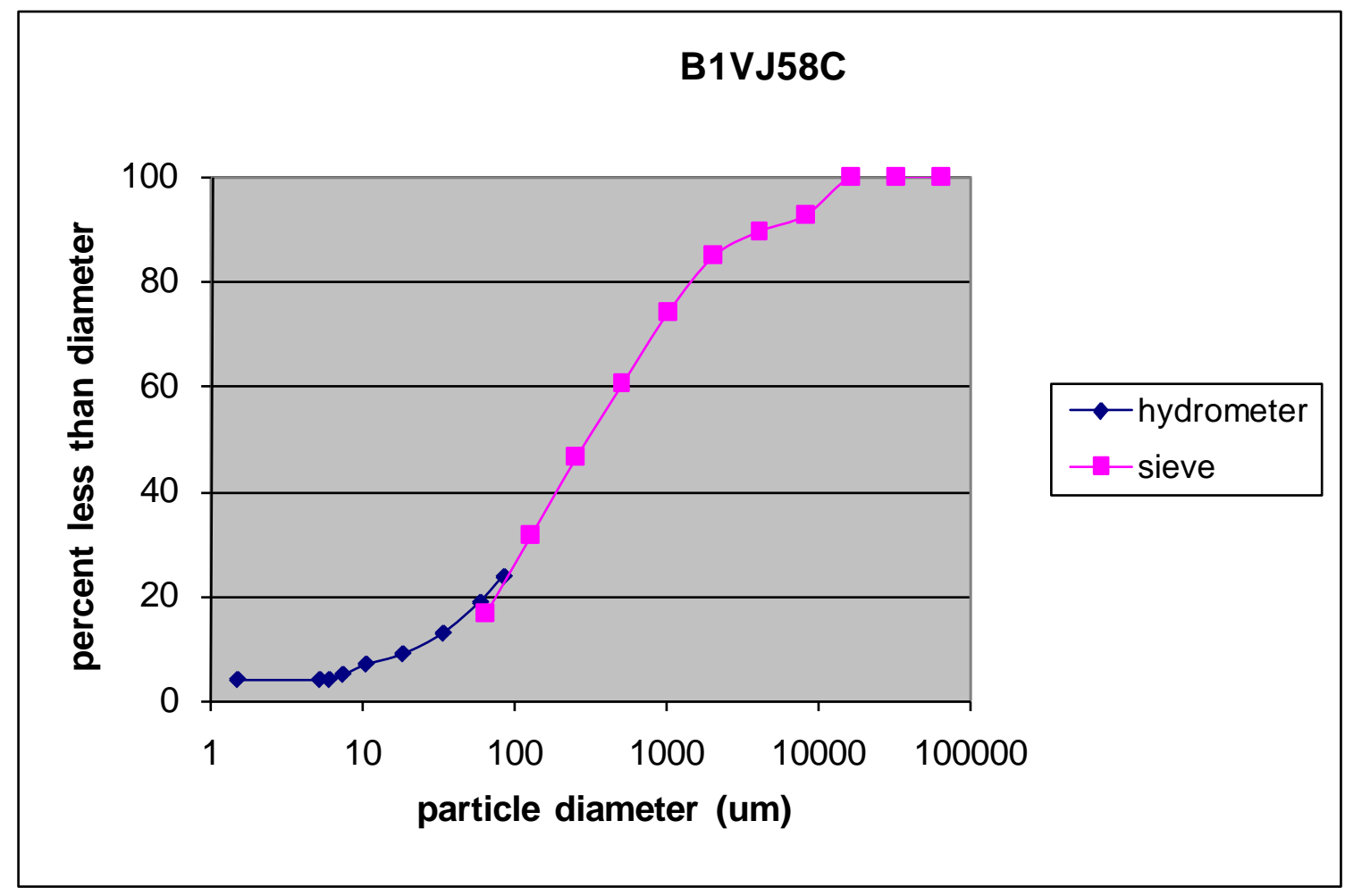

Figure 1. Graph of hydrometer and sieving results for sample B1VJ58C

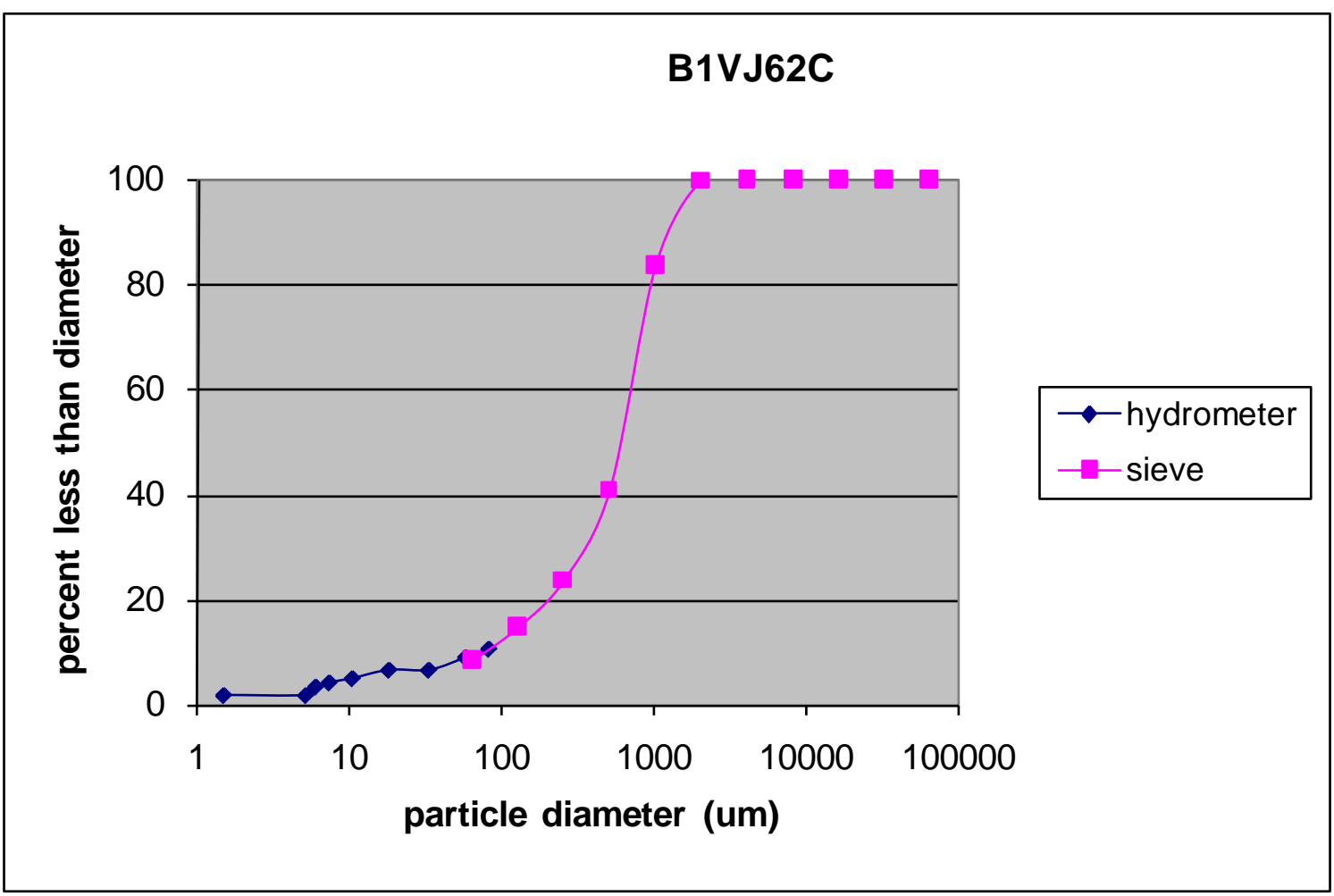

Figure 2. Graph of hydrometer and sieving results for sample B1VJ62C 


\subsubsection{U-236 Analysis}

Table 2. U-235, U-236 and U-238 results (in counts per second) for sample B1VJ58A

\begin{tabular}{|c|c|c|c|c|}
\hline & $\begin{array}{c}\text { mid-depth } \\
\mathrm{ft}\end{array}$ & $\begin{array}{c}\mathrm{U} 235 \\
\mathrm{cps}\end{array}$ & $\begin{array}{c}\mathrm{U} 236 \\
\mathrm{cps}\end{array}$ & $\begin{array}{c}\mathrm{U} 238 \\
\mathrm{cps}\end{array}$ \\
\hline Water Extract & & & & \\
\hline B1VJ58A & 43.25 & $7.10 \mathrm{E}+04$ & $4.43 \mathrm{E}+03$ & $8.29 \mathrm{E}+06$ \\
\hline Acid Extract & & & & \\
\hline B1VJ58A & 43.25 & $4.17 \mathrm{E}+04$ & $1.60 \mathrm{E}+03$ & $5.18 \mathrm{E}+06$ \\
\hline
\end{tabular}

\subsubsection{Uranium Desorption $\mathrm{K}_{\mathrm{d}}$ Estimates}

Table 3. Estimated Uranium $\mathrm{K}_{\mathrm{d}}(\mathrm{ml} / \mathrm{g})$ desorption values

\begin{tabular}{|c|c|c|c|c|c|c|}
\hline & $\begin{array}{c}\text { Mid-depth } \\
\text { ft }\end{array}$ & $\begin{array}{c}\text { Acid extractable } \\
\text { Uranium } 238 \\
\mu g / g \text { dry }\end{array}$ & $\begin{array}{c}\text { Water extractable } \\
\text { Uranium } 238 \\
\mu \mathrm{g} / \mathrm{g} \text { dry }\end{array}$ & $\begin{array}{c}\text { Cl } \\
\mu \mathrm{g} / \mathrm{ml}\end{array}$ & $\begin{array}{c}\text { Ca } \\
\mu g / g \text { dry }\end{array}$ & $\begin{array}{c}\mathrm{Kd} \\
\mathrm{ml} / \mathrm{g}\end{array}$ \\
\hline B1VJ54B & 9.75 & $1.01 \mathrm{E}+00$ & 9.84E-02 & $9.98 \mathrm{E}-03$ & $9.12 \mathrm{E}-01$ & $9.13 \mathrm{E}+01$ \\
\hline B1VJ55C & 15.25 & 3.84E-01 & 3.93E-03 & 3.99E-04 & $3.80 \mathrm{E}-01$ & $9.52 \mathrm{E}+02$ \\
\hline B1VJ56C & 26.25 & 3.11E-01 & $6.90 \mathrm{E}-03$ & $1.23 \mathrm{E}-03$ & 3.04E-01 & $2.47 \mathrm{E}+02$ \\
\hline B1VJ56B & 26.75 & 3.18E-01 & 2.90E-02 & 3.59E-03 & 2.89E-01 & $8.04 \mathrm{E}+01$ \\
\hline B1VJ56A & 27.25 & 2.88E-01 & $9.66 \mathrm{E}-03$ & $1.21 \mathrm{E}-03$ & $2.78 \mathrm{E}-01$ & $2.31 \mathrm{E}+02$ \\
\hline B1VJ58C & 42.25 & 5.01E-01 & $1.88 \mathrm{E}-01$ & 1.50E-02 & 3.13E-01 & $2.08 \mathrm{E}+01$ \\
\hline B1VJ58B & 42.75 & 5.27E-01 & 3.18E-01 & $2.34 \mathrm{E}-02$ & $2.09 \mathrm{E}-01$ & $8.94 \mathrm{E}+00$ \\
\hline B1VJ58A & 43.25 & 7.53E-01 & 4.59E-01 & 3.67E-02 & $2.94 \mathrm{E}-01$ & $8.01 \mathrm{E}+00$ \\
\hline B1VJ59C & 59.25 & $3.16 \mathrm{E}-01$ & $1.70 \mathrm{E}-03$ & $2.53 \mathrm{E}-04$ & $3.14 \mathrm{E}-01$ & $1.24 \mathrm{E}+03$ \\
\hline B1VJ59B & 59.75 & 3.15E-01 & ND & & & \\
\hline B1VJ59A & 60.25 & 3.65E-01 & ND & & & \\
\hline B1VJ60C & 75.25 & 3.76E-01 & $7.66 \mathrm{E}-04$ & $1.88 \mathrm{E}-04$ & $3.75 \mathrm{E}-01$ & $1.99 \mathrm{E}+03$ \\
\hline B1VJ60B & 75.75 & 3.34E-01 & $6.47 \mathrm{E}-04$ & $1.22 \mathrm{E}-04$ & 3.33E-01 & $2.73 \mathrm{E}+03$ \\
\hline B1VJ60A & 76.25 & 3.66E-01 & ND & & & \\
\hline B1VJ61C & 95.25 & 3.11E-01 & ND & & & \\
\hline B1VJ61B & 95.75 & 2.93E-01 & ND & & & \\
\hline B1VJ61A & 96.25 & 3.39E-01 & ND & & & \\
\hline B1VJ62C & 133.25 & 2.94E-01 & 8.87E-04 & 1.07E-04 & 2.93E-01 & $2.74 \mathrm{E}+03$ \\
\hline B1VJ62B & 133.75 & 3.59E-01 & ND & & & \\
\hline B1VJ62A & 134.25 & 3.63E-01 & ND & & & \\
\hline B1VJ64C & 170.25 & 3.53E-01 & $5.66 \mathrm{E}-04$ & 9.31E-05 & 3.52E-01 & $3.79 \mathrm{E}+03$ \\
\hline B1VJ64B & 170.75 & 3.16E-01 & ND & & & \\
\hline B1VJ64A & 171.25 & 2.31E-01 & ND & & & \\
\hline
\end{tabular}

$\mathrm{ND}=$ Not detectable

\subsection{UPR 200-E-86}

\subsubsection{Particle Size Analysis}


Table 4. Hydrometer and sieving results for UPR 200-E-86

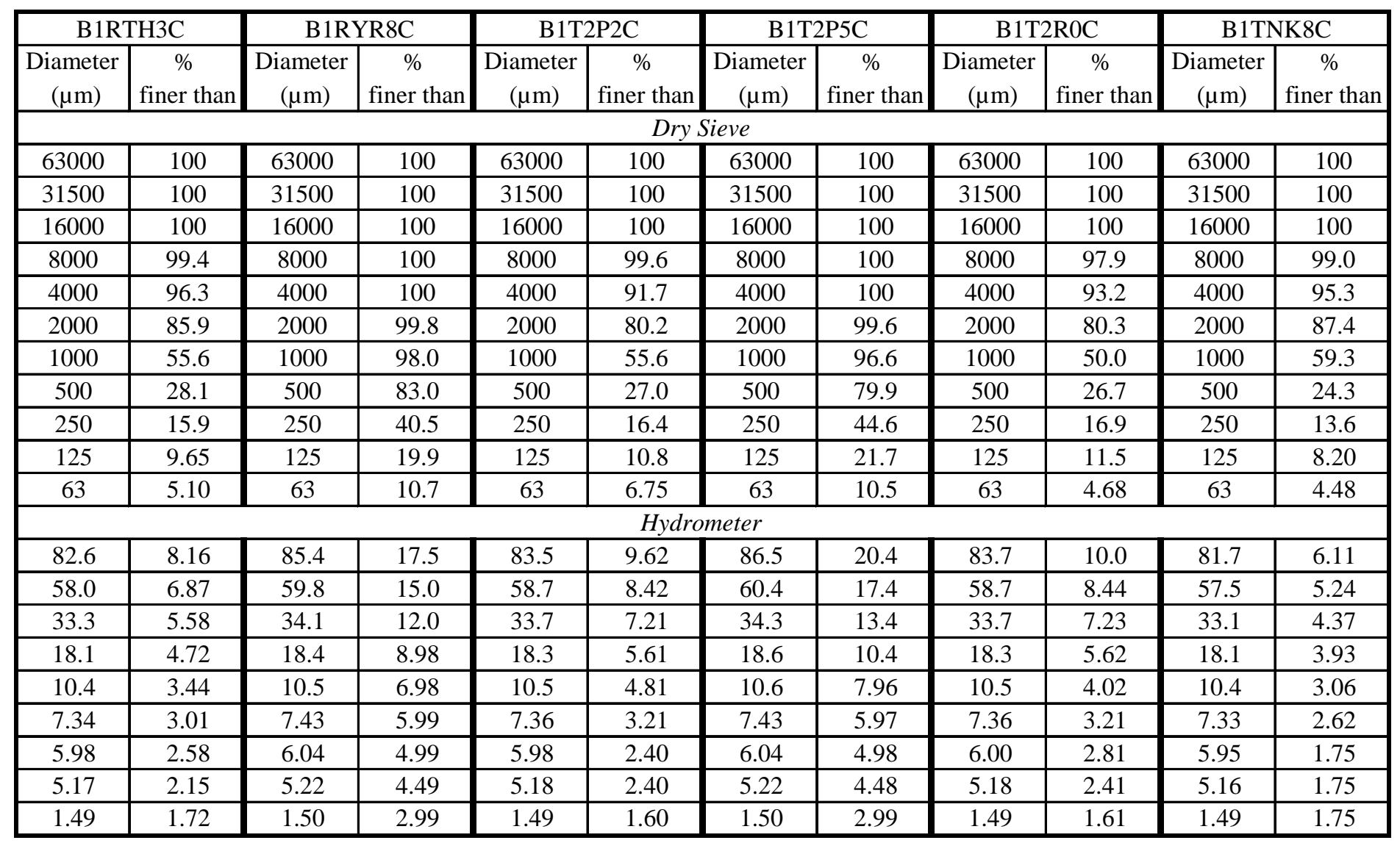




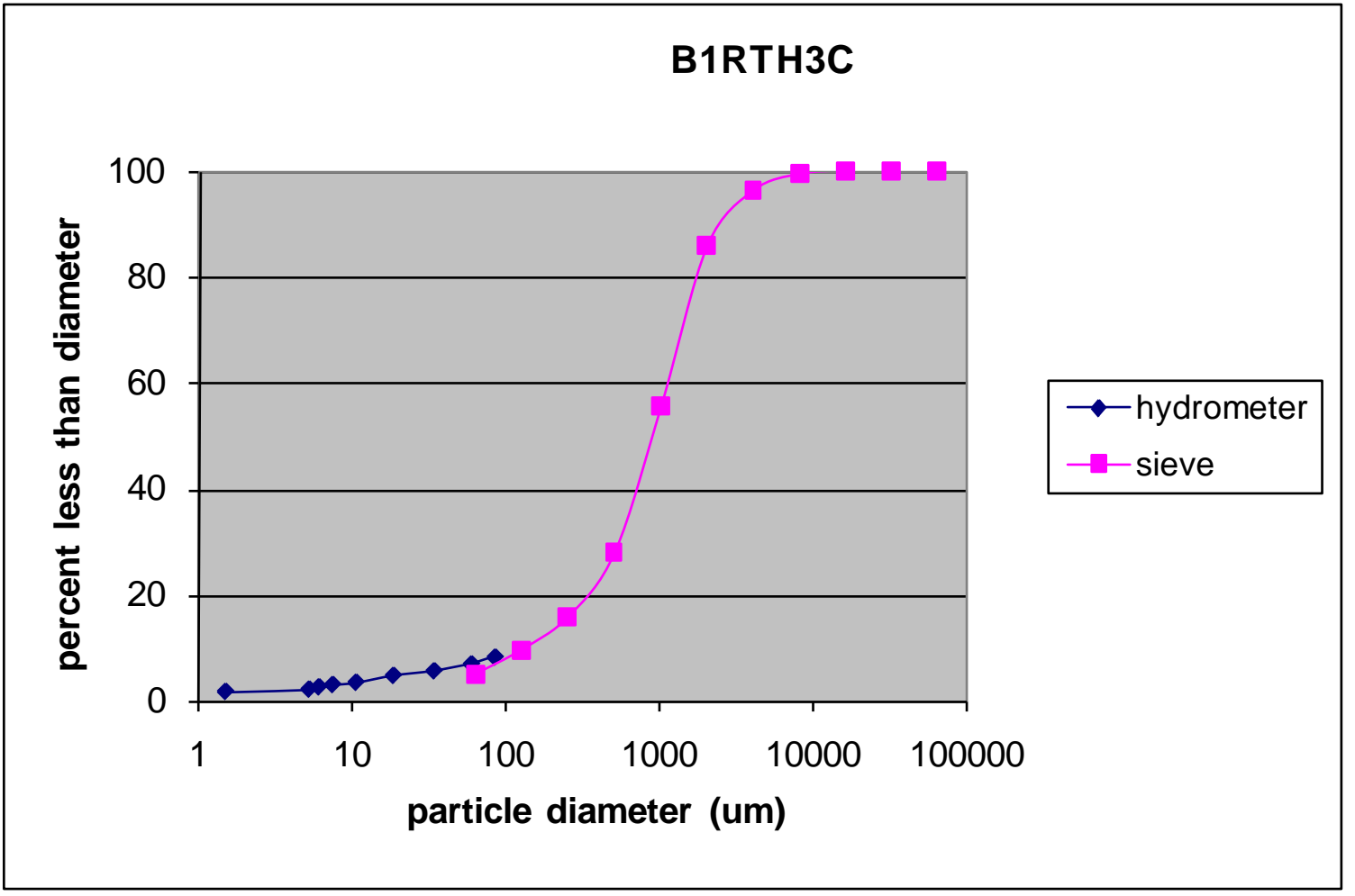

Figure 3. Graph of hydrometer and sieving results for sample B1RTH3C

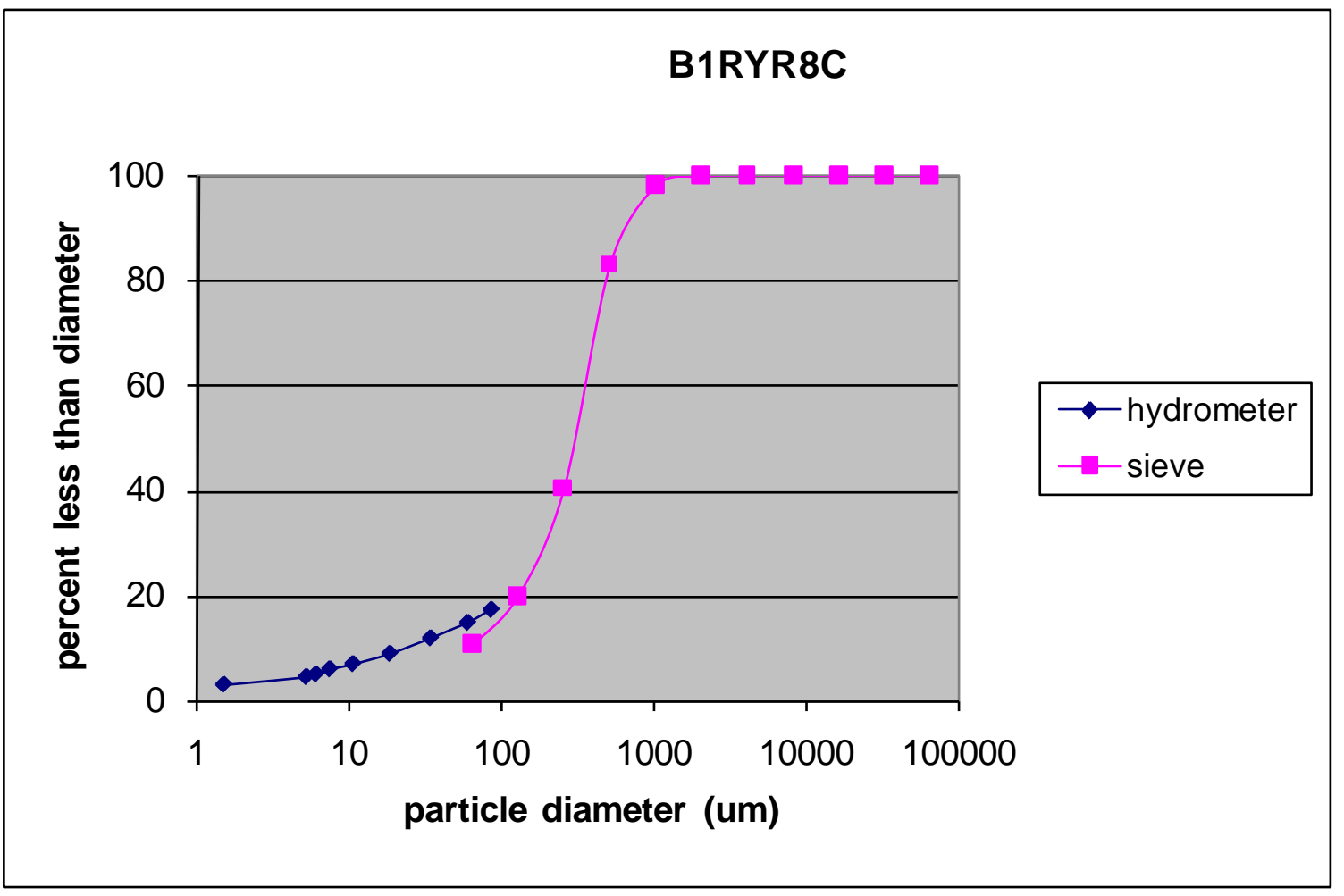

Figure 4. Graph of hydrometer and sieving results for sample B1RYR8C 


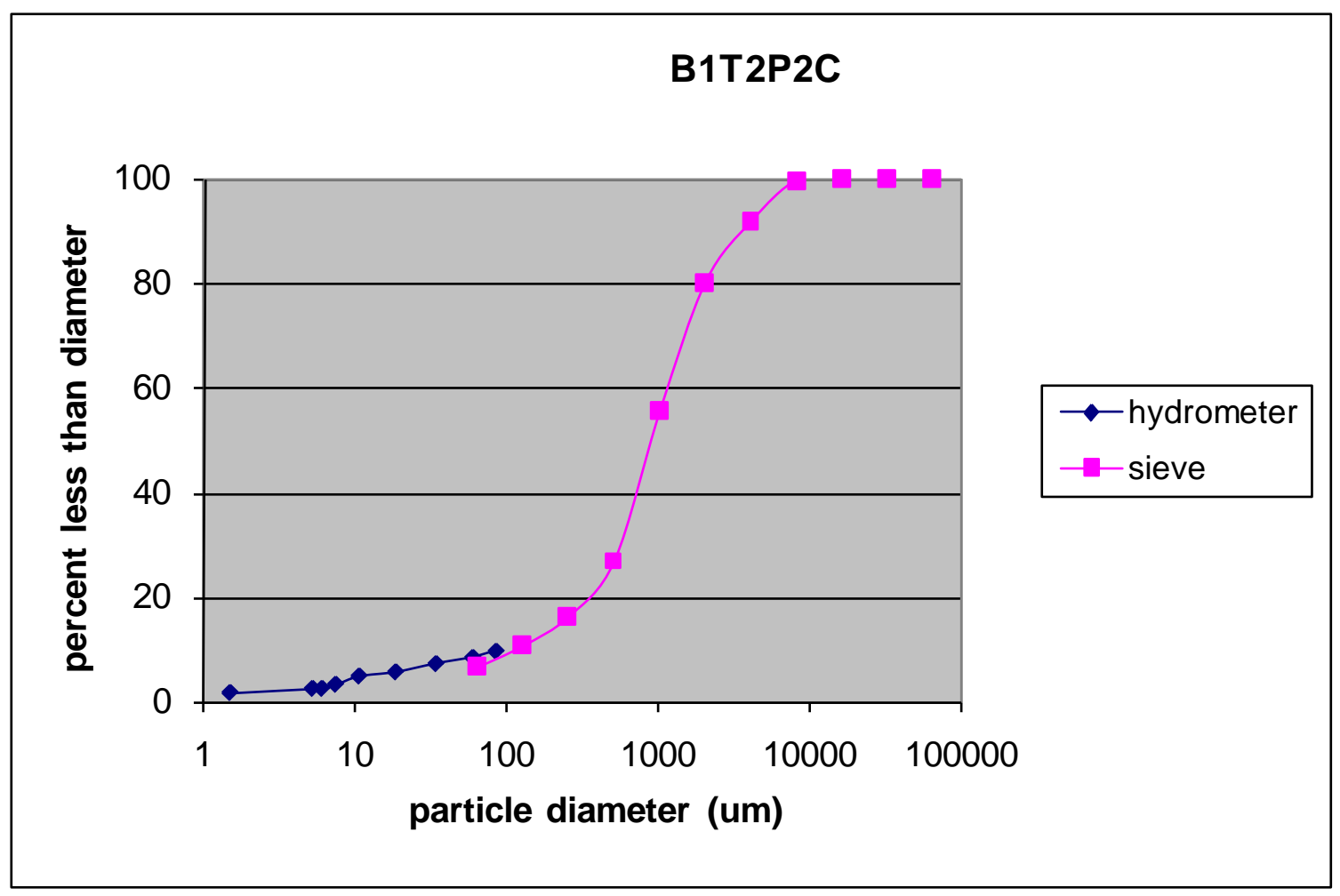

Figure 5. Graph of hydrometer and sieving results for sample B1T2P2C

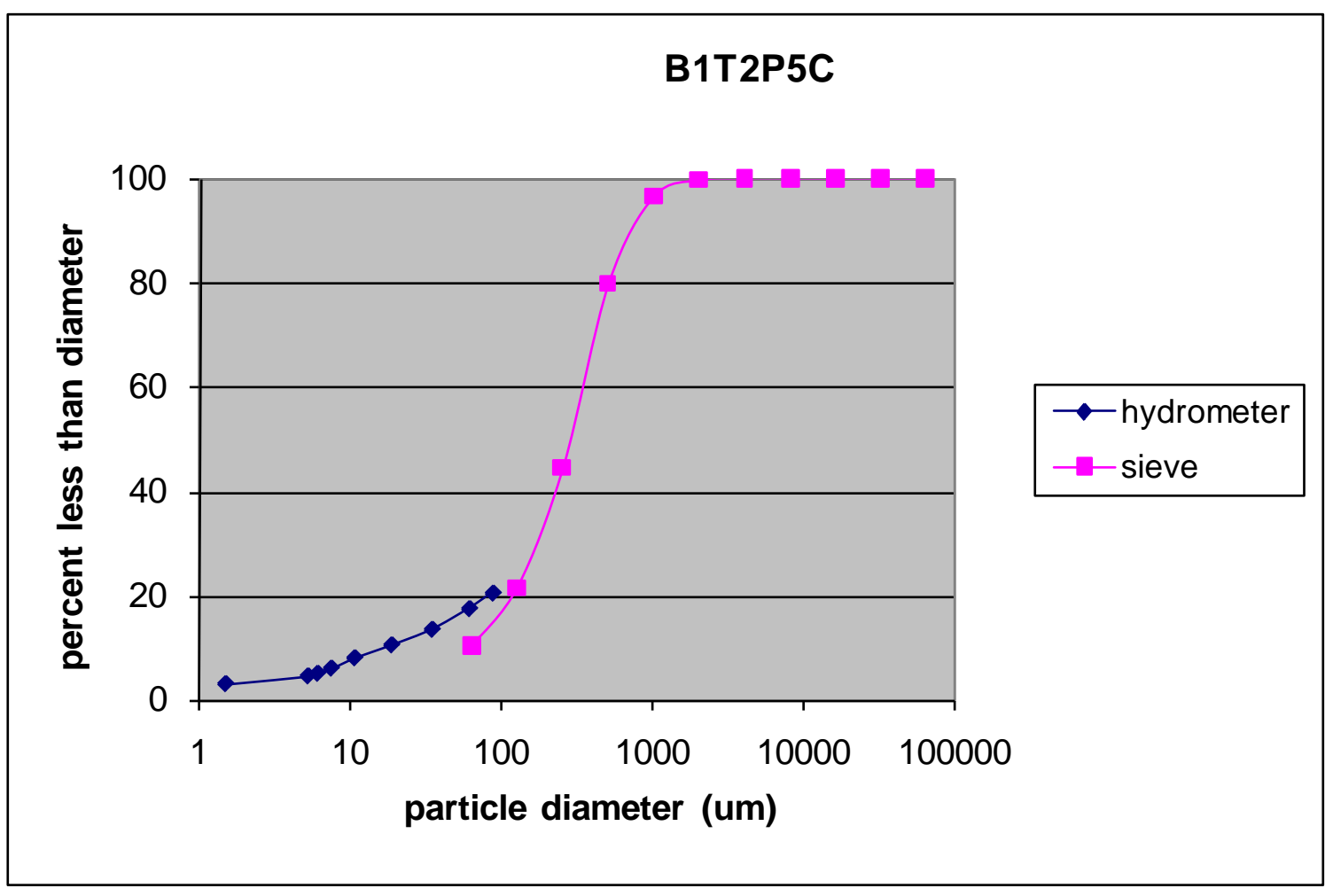

Figure 6. Graph of hydrometer and sieving results for sample B1T2P5C 


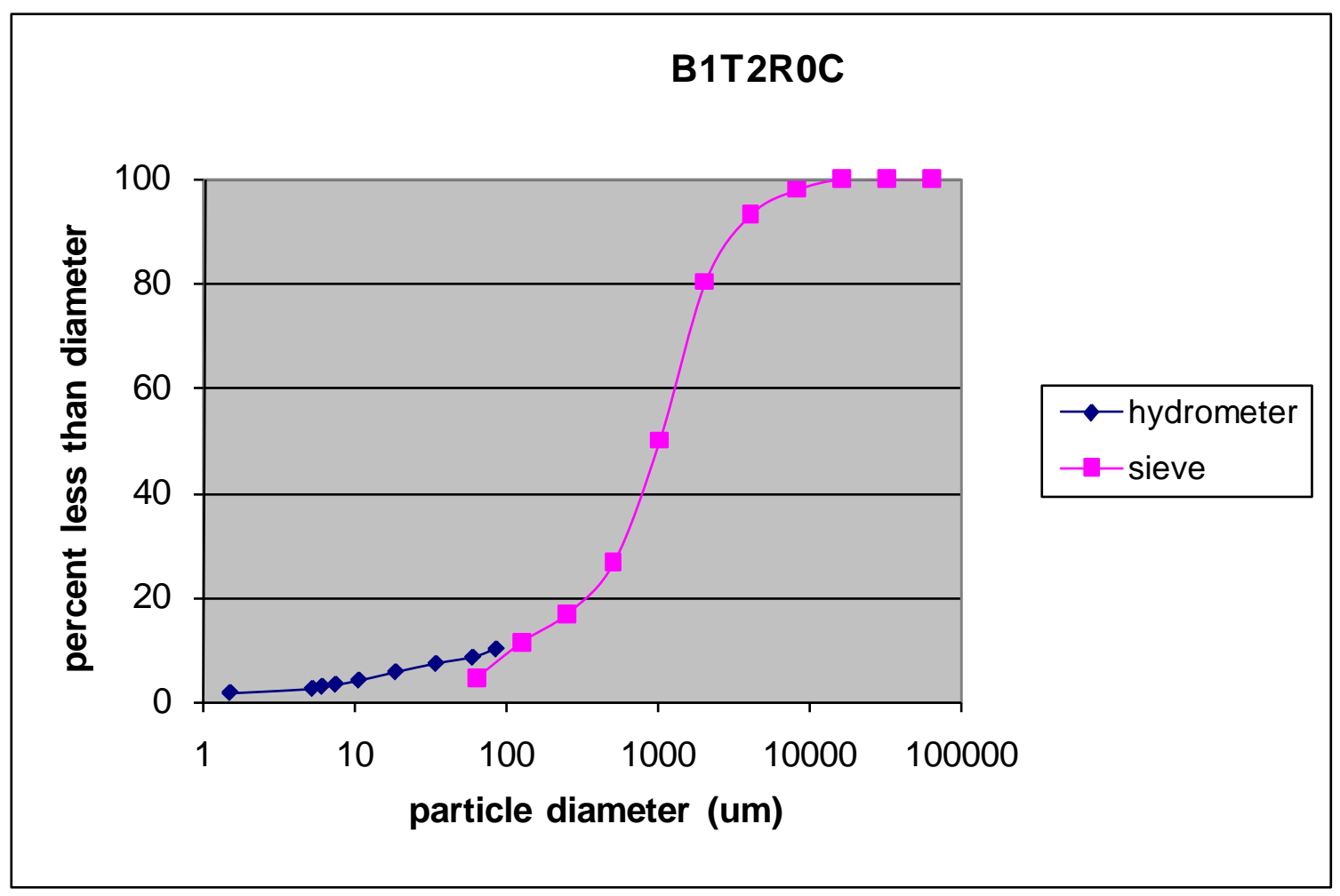

Figure 7. Graph of hydrometer and sieving results for sample B1T2R0C

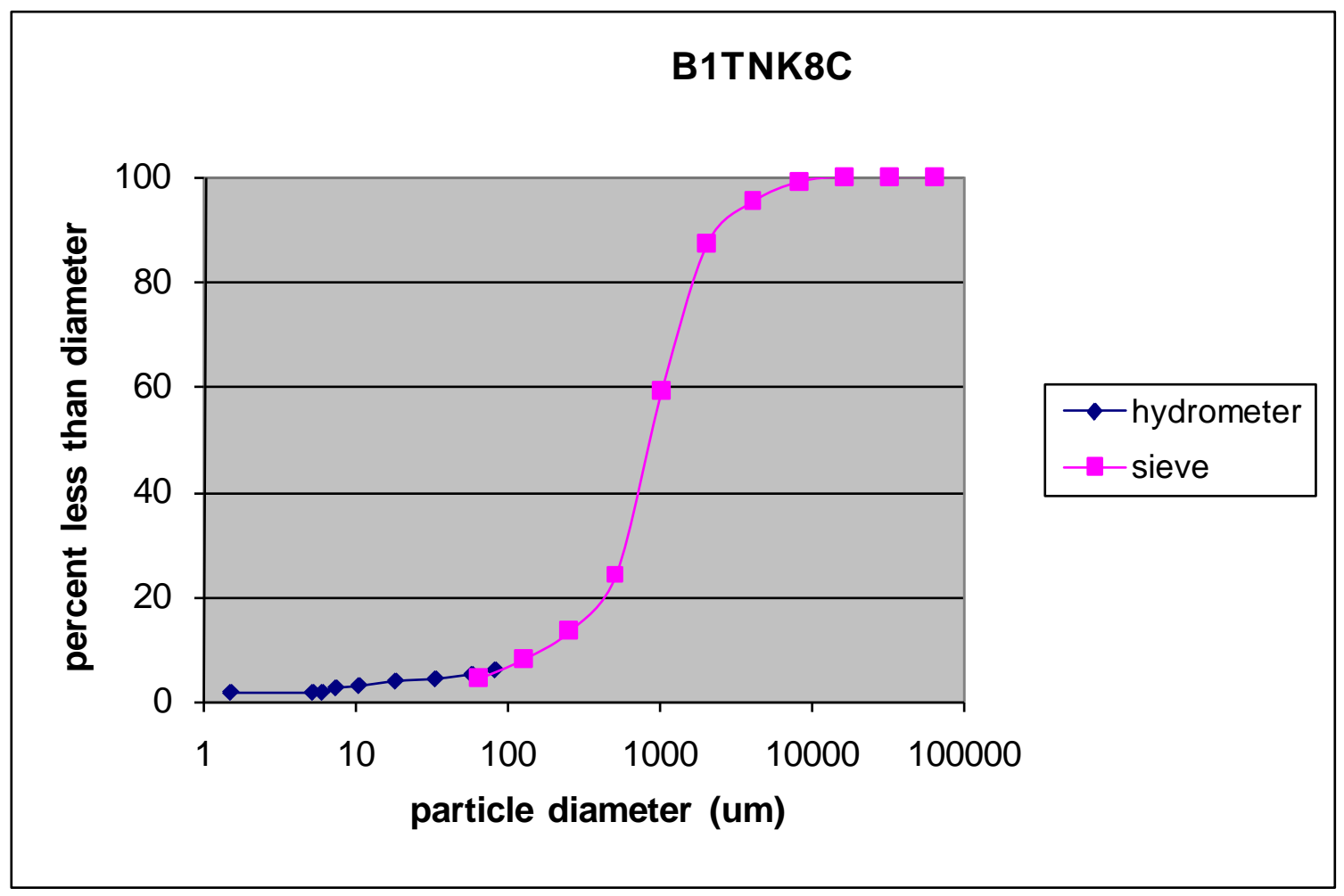

Figure 8. Graph of hydrometer and sieving results for sample B1TNK8C 


\subsection{XRD}

Characterization of the bulk sediments $(<2 \mathrm{~mm})$ by XRD revealed the mineralogy was similar for all 8 samples. The sediments are dominated by quartz and feldspar (both plagioclase and alkali-feldspar), with lesser amounts of amphiboles and clays, primarily mica and chlorite. Since bulk powder XRD results are similar, only one XRD tracing will be presented. A complete set of bulk powder results are shown in Appendix A. Observations conducted on the XRD tracing taken from sediment B1VJ58C is provided in Figure 9. For comparison purposes, diffraction data taken from PDFTM database for quartz (46-1045), illite (26-0911), chlorite (clinochlore) (29-0701), albite (10-0393), hastingsite (amphibole) (20-0469), microcline (19-0932) are provided in Figure 9.

The main reflection for quartz is at $26.63^{\circ} 2 \theta$, followed by less intense reflections at $20.86^{\circ}, 36.53^{\circ}$, $39.46,{ }^{\circ} 42.43^{\circ}, 50.12^{\circ}$, and $59.92^{\circ} 2 \theta$. Illite and chlorite are identified by the low angle reflections positioned at $8.7^{\circ}$ and $6.2^{\circ} 2 \theta$, respectively. Smectites are difficult to detect using a bulk powder mount, but are identified in the clay fraction using a different sample mounting technique (described below). The main reflections associated with feldspar minerals are between $27.34^{\circ}$ and $27.92^{\circ} 2 \theta$, with the higher $2 \theta$ values belonging to the plagioclase series. The presence of amphibole was established by the characteristic $100 \%$ reflection at $10.5^{\circ} 2 \theta$.

Sediment B1VJ58C also produced several minor reflections on the xrd tracing that were not assigned to a crystalline phase. These reflections were positioned at $23.20^{\circ}, 32.21^{\circ}, 36.18^{\circ}, 42.19^{\circ}$, and $48.35^{\circ} 2 \theta$.

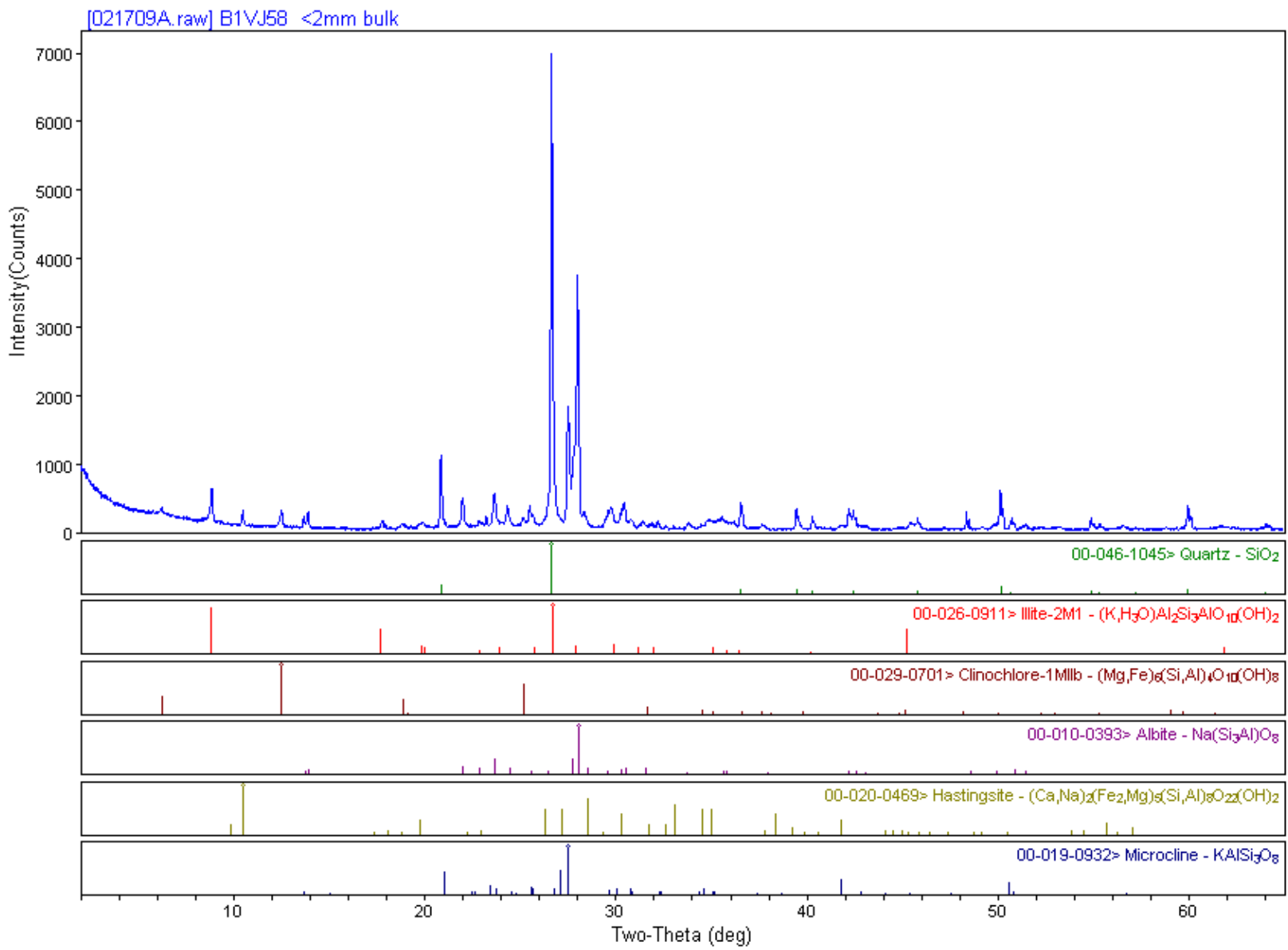

Figure 9. Bulk powder XRD tracings of randomly oriented specimen from sample B1VJ58C. The scan was collected from $2^{\circ}$ to $65^{\circ} 2 \theta$ with a $0.02^{\circ}$ step and 2-second dwell time. 
Because this sediment contained elevated concentrations of nitrate (compared to other B1VJ58C sediments), a comparison of the XRD tracing to known nitrate compounds such as nitratine $\left(\mathrm{NaNO}_{3}\right)$ was conducted. No matches of known nitrate compounds were identified. Additionally, sediment B1T2ROC produced one minor reflection $\left(34.04^{\circ} 2 \theta\right)$ on the XRD tracing that was not assigned to a crystalline phase. Both of these samples would require more detailed XRD characterization (slower scan speeds and longer dwell times) to better determine if these reflections are part of another crystalline phase not yet identified in these sediments.

For clay characterization, XRD tracings were collected of the Mg-saturated, ethylene glycol solvated $<2.0 \mu \mathrm{m}$ fractions from oriented mounts of each sample. Results obtained by XRD analysis were similar for all samples and indicate three primary clay minerals: smectite, chlorite, and illite. Minor amounts of non clay minerals such as quartz and in some cases feldspar were also identified as occurring in the clay fraction. Examples of individual xrd scans of the clay fraction are provided in Appendix B.

A typical clay pattern, shown in Figure 10, illustrates the various reflections associated with clay minerals. Smectite is the fraction of the Mg-saturated sub-sample that gives a basal reflection of $5.3^{\circ} 2 \theta$. after solvation with ethylene glycol (Figure 10). Illite (mica) is the easiest of the three clay minerals to identify in the clay assemblage. Basal reflections for illite are at $8.8^{\circ}, 17.8^{\circ}$, and $26.7^{\circ} 2 \theta$. Chlorite is identified by a basal series of diffraction peaks at $6.2^{\circ}, 12.5^{\circ}, 18.8^{\circ}$, and $25.2^{\circ} 2 \theta$, which are unaffected

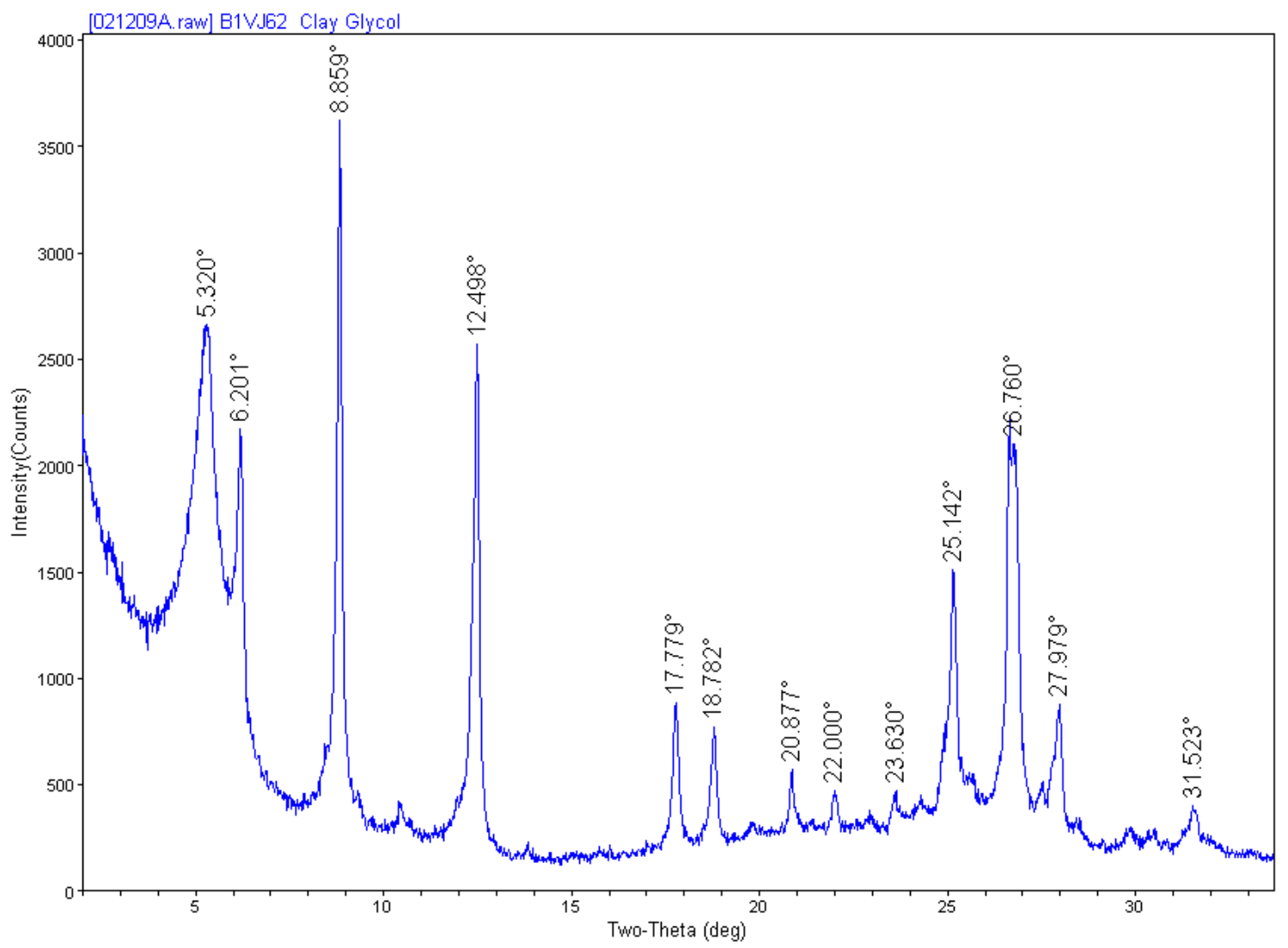

Figure 10. XRD tracings of preferentially oriented $<2.0 \mu \mathrm{m}$ fraction (B1TNK8C). Data was collected from $2^{\circ}$ to $45^{\circ} 2 \theta$ with a $0.02^{\circ}$ step and 2-second dwell time.

by cation saturation $\left(\mathrm{Mg}^{2+}, \mathrm{K}^{+}\right)$or ethylene glycol solvation. Kaolinite is difficult to identify in the presence of chlorite. Basal reflections characteristic of kaolinite are at $12.5^{\circ}$ and $24.9^{\circ} 2 \theta$ and are 
superimposed on the even-ordered chlorite reflections. Kaolinite reflections are unaffected by cation saturation and ethylene glycol solvation. Indication of kaolinite in the presence of chlorite can be accomplished by differentiating the kaolinite basal reflection at $24.9^{\circ} 2 \theta$, from the chlorite reflection at $25.2^{\circ} 2 \theta$ (Moore and Reynolds, 1989). Based on this technique, no kaolinite was detected in these samples. Positive identification of kaolinite would require additional characterization techniques such as transmission electron microscopy. Identification of quartz and feldspar, based on reflections positioned at $20.87^{\circ}$ and $27.98^{\circ} 2 \theta$, respectively, were observed in minor amounts for each clay sample. No other crystalline phases were detected by XRD as being present in the clay fractions.

\subsection{1-C Tank Farm Paleosol Geology}

Reidel (2005) attempted to correlate two paleosols observed in the vicinity of the IDF facility within the southern 200 East Area (Figure 12). Immature paleosols (buried soil horizons) were identified as thin layers (several inches to $1 \mathrm{ft}$ thick), with evidence of bioturbation and weak calcic horizons, representing short periods of subaerial weathering (few dozen to few hundred years) between cataclysmic Ice Age floods, which deposited the Hanford formation in the Pasco Basin.

In summary, the correlation of IDF paleosols northward to the C Tank Farm is not simple or straightforward. For one reason, paleosols are discontinuous as shown in Figure 12. The Layer 1 paleosol (Figure 1A) was only identified in 5 of 26 wells ( $<20 \%$ ) in the vicinity of IDF (Reidel 2005). The younger Layer 2 paleosol (Figure 12B) was identified in 16 of the same 25 wells (64\%) around the IDF. The discontinuous nature of the paleosols is not surprising considering their extremely thin nature and difficulty in identifying weak paleosol horizons in boreholes. 

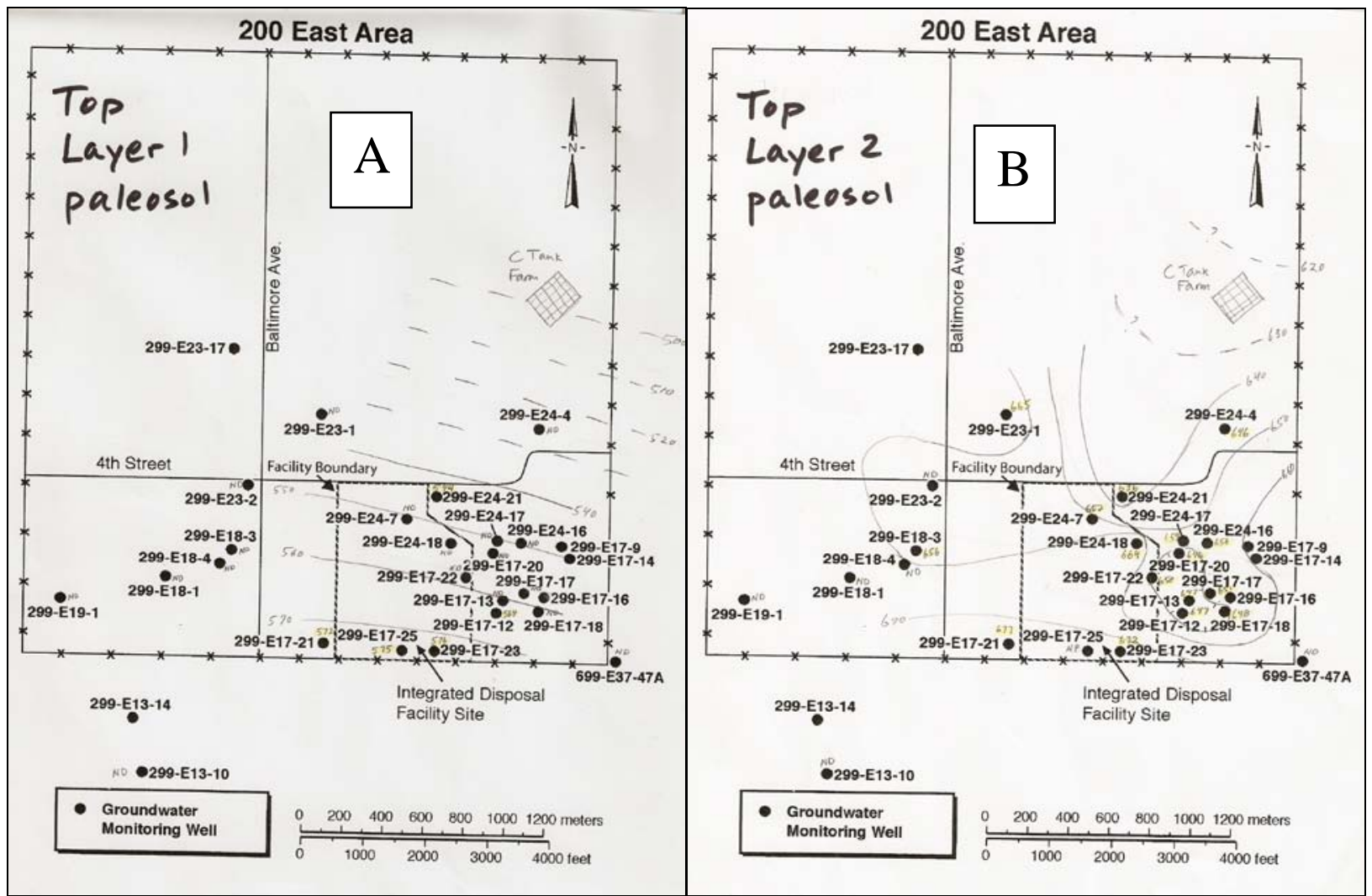

Figure 11. Wells in vicinity of IDF where presence of paleosols were evaluated (Reidel 2005). A. Top of Layer 1 paleosol; B. Top of Layer 2 paleosol. Added are the elevations (from Reidel 2005) and best estimate of structure contours on the top of the paleosols, projected towards C Tank Farm. The highly discontinuous nature of the paleosols, especially for Layer 1 , is apparent. ND = not detected, NP = not present.

For the present exercise, the tops of the paleosols, reported in Reidel (2005) were added to Figure 12 and hand contoured; this contoured surface was projected northeastward toward C Tank farm. In Figure 12A the Layer 1 paleosol appears to dip moderately toward the northeast. However this is based on very few boreholes ( 5 of 26) where the paleosol was actually identified. Also problematic is the highly uneven nature of the Layer 2 paleosol (Figure 12B). Sand-dominated Ice Age flood deposits, like those deposited in the vicinity of the IDF were deposited as broad, low-relief sheets across Cold Creek Bar (Bjornstad 2006). The relief shown in Figure 12 is not consistent with the low relief observed on Cold Creek Bar. This may suggest that more than a single surface is being contoured or the surface was falsely identified in Figure 12B.

Assuming the paleosols do extend from the IDF facility to the $\mathrm{C}$ tank Farm as indicated in Figure 12, which is doubtful as explained below, we might expect to see the Layer 1 paleosol at about 500 -ft elevation and the Layer 2 paleosol at about the 625-ft elevation (Figure 12). Because the land surface around C Tank Farm slopes to the northeast, the depth to these paleosols would vary, however. Again, assuming the projection is accurate, the top of the Layer 1 paleosol in north side of C Tank Farm would lie between 140-150 ft depth, and along the south side $\sim 160-170 \mathrm{ft}$ deep. A projection of the top of the Layer 2 paleosol would place the contact at the north end of C Tank Farm at 20-30 ft depth, and 30-40 ft depth at the south end.

The possibility that paleosols from the IDF correlate to C Tank Farm seems highly unlikely, however. Trying to correlate thin, weakly developed paleosols, even over a short distance is problematic; trying to correlate these strata further afield (e.g., C Tank Farm) is even more of a problem and I believe a fruitless and misleading exercise. The energy of the Ice Age floods that deposited the Hanford formation increases to the north in the direction of C Farm. This is reflected in the type of sediment deposited at IDF (moderate-energy flood sands all the way to the surface) vs. C Tank Farm, which has thick layer (up to $120 \mathrm{ft}$ ) of high-energy 
flood gravel over the surface (Wood et al. 2003). This represents a facies change whereby higher energy gravel at C Tank Farm was deposited at the same time as lower energy sand at IDF during Ice Age floods. Higher energy flood currents at C Tank Farm would have likely eroded away and destroyed any paleosols that formed in this area. Thus, paleosols, which survived erosion at the IDF, should not be expected at C Tank Farm. This is especially true for the Layer 2 paleosol, which when projected to C Tank Farm lies within the high-energy gravel-dominated flood sequence (H1 unit). Flood currents would have certainly stripped away any paleosols that developed between floods in this area. 


\subsection{References}

American Society of Agronomy (ASA). 1986a. "Hydrometer Method.” Chapter 15-5 in Methods of Soil Analysis-Part 1, 2nd Edition of Physical and Mineralogical Methods, SSSA Book Series No. 5, ed. A Klute, pp. 404-408. Soil Science Society of America, Madison, Wisconsin.

American Society for Testing and Materials (ASTM) D6913-04. 2004. "Standard Test Method for Particle-size Distribution (Gradation) of Soils Using Sieve Analysis.” American Society for Testing and Materials, West Conshohocken, Pennsylvania.

Bjornstad, B.N. 2006, On the Trail of the Ice Age Floods: A Geological Field Guide to the MidColumbia Basin, Keokee Co. Publishing, Inc., Sandpoint, Idaho.

Clayton ET. 2008. "Inductively Coupled Plasma Mass Spectrophotometry (ICP-MS) Analysis.” PNNL-AGG-415 (Rev. 2). Unpublished PNNL technical procedure, Pacific Northwest National Laboratory, Richland, Washington.

Drever, J.I., 1973. Preparation of oriented clay mineral specimens for x-ray-diffraction analysis by a filter-membrane peel technique. American Mineralogist 58, 553-554.

Moore, D.M., Reynolds, R.C., 1989. X-Ray Diffraction and the Identification and Analysis of Clay Minerals. Oxford University Press, Oxford, New York.

Reidel, S.P., 2005, Geologic data package for the 2005 Integrated Disposal Facility waste performance assessment, PNNL-14586, Rev. 1, Pacific Northwest National Laboratory, Richland, Washington.

Wood, M. I., B.N. Bjornstad, D.G. Horton, S.M. Narbutovskih, and R. Schalla, 2003, Subsurface conditions description of the C and A-AX Waste Management Area, RPP-14430, Rev. 0, CH2MHill Hanford Group, Inc., Richland, Washington. 


\subsection{Appendix A - Bulk Powder XRD Scans}

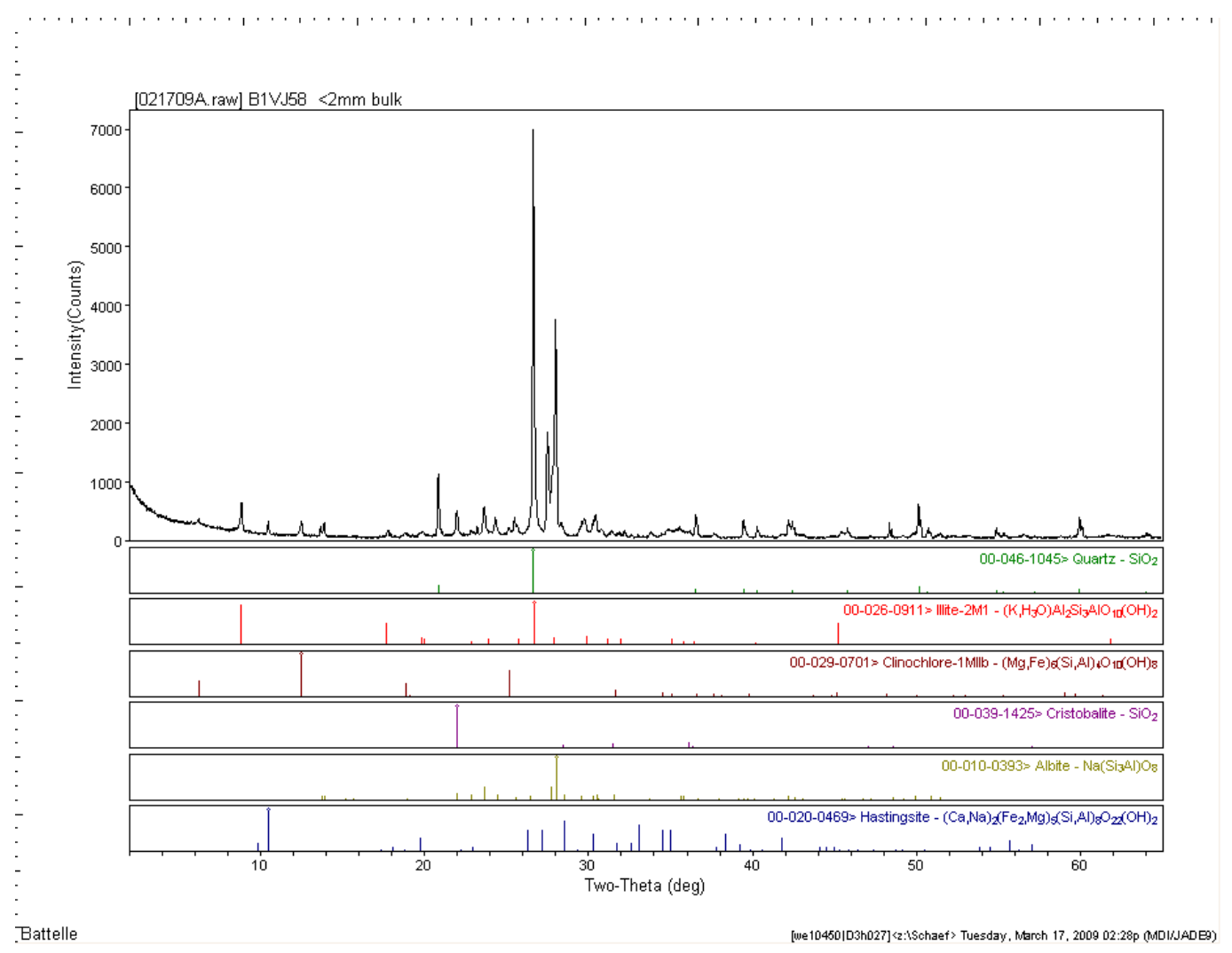



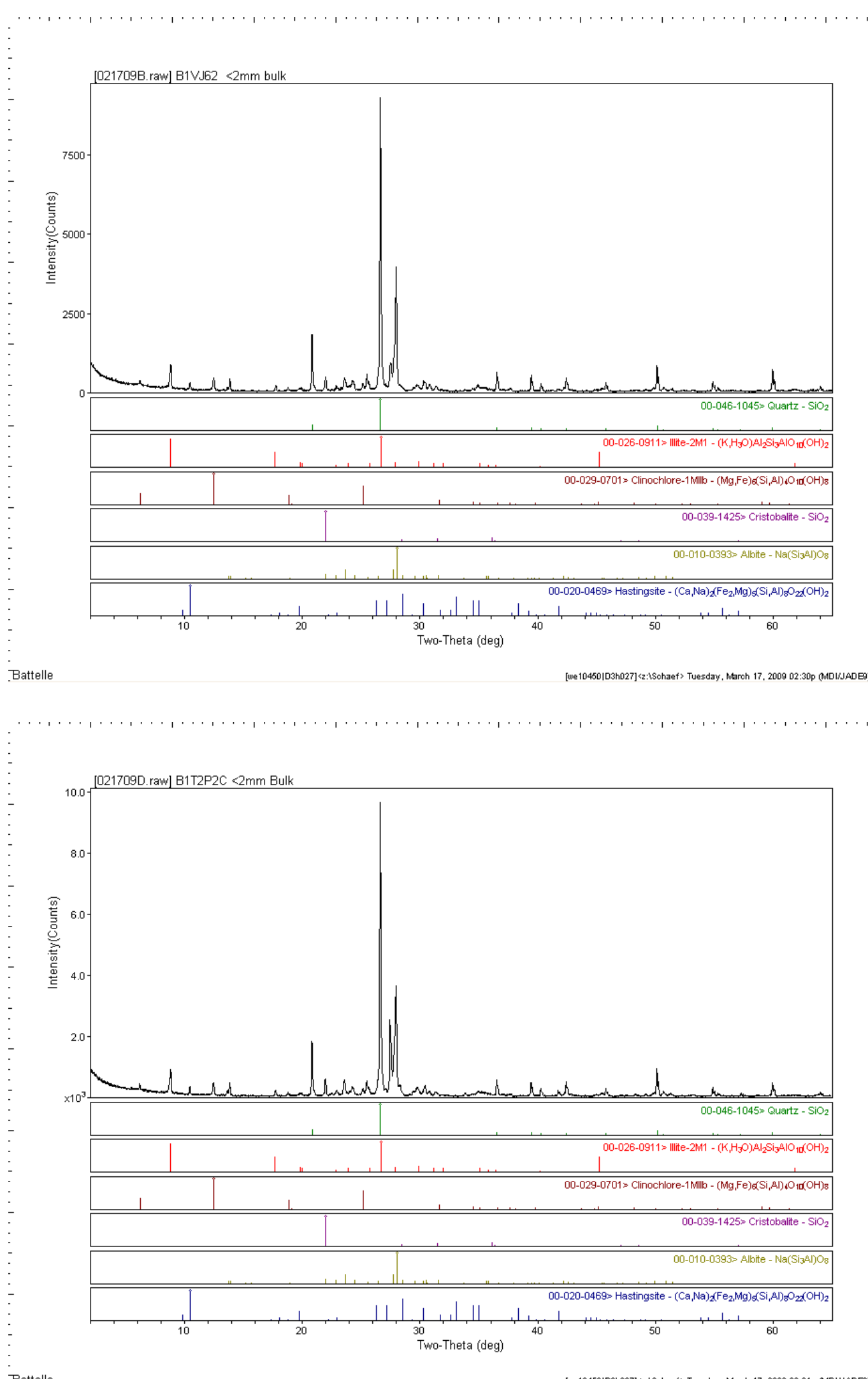

Battelle

[we 10450|[3h027]〈z:LSchaef> Tuesday, March 17, 2009 02:31p (MDI/JADE9) 

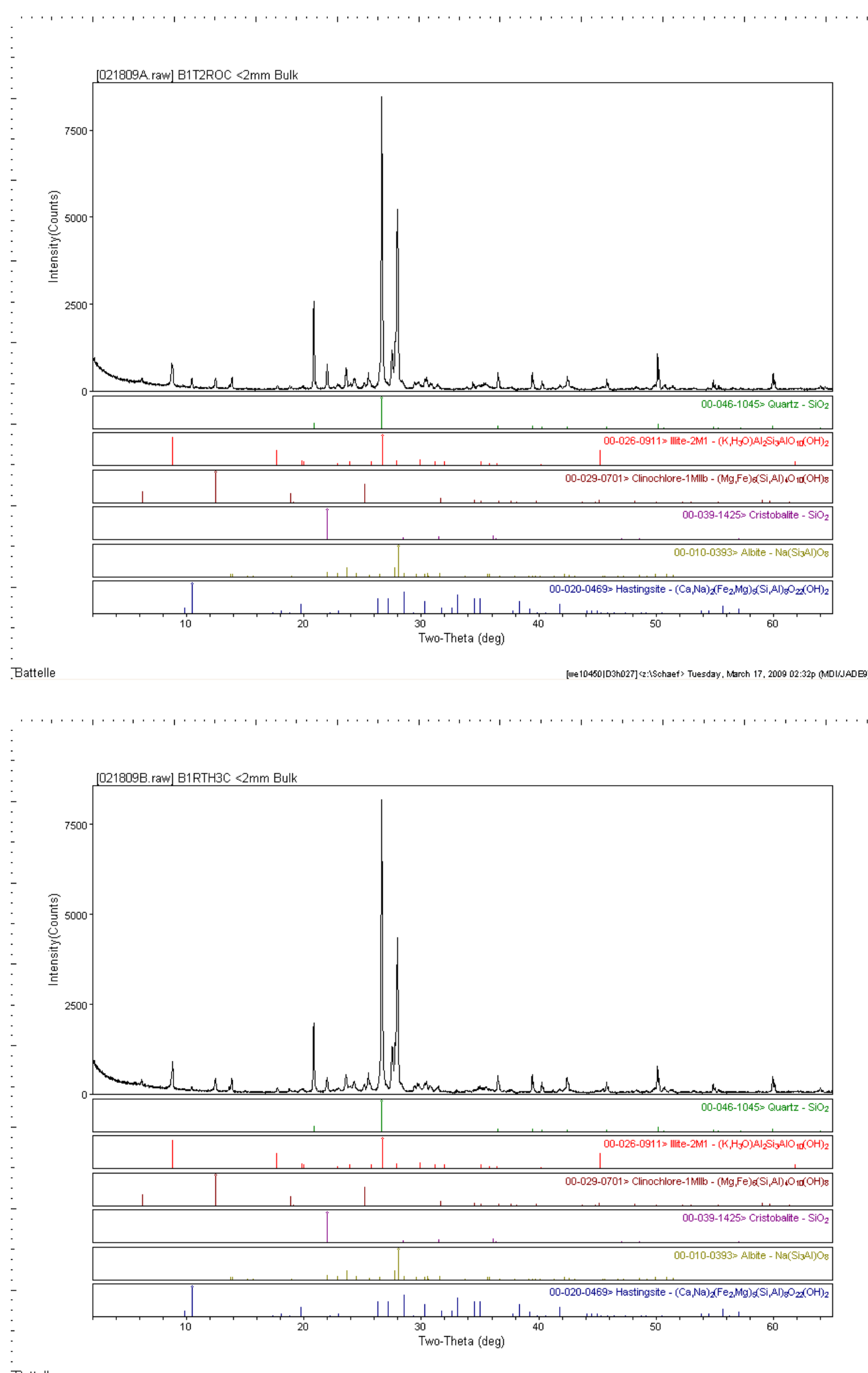

Battelle

[we 10450|[3h027]〈z:LSchaef> Tuesday, March 17, 2009 02:32p (MDI/JADE9) 

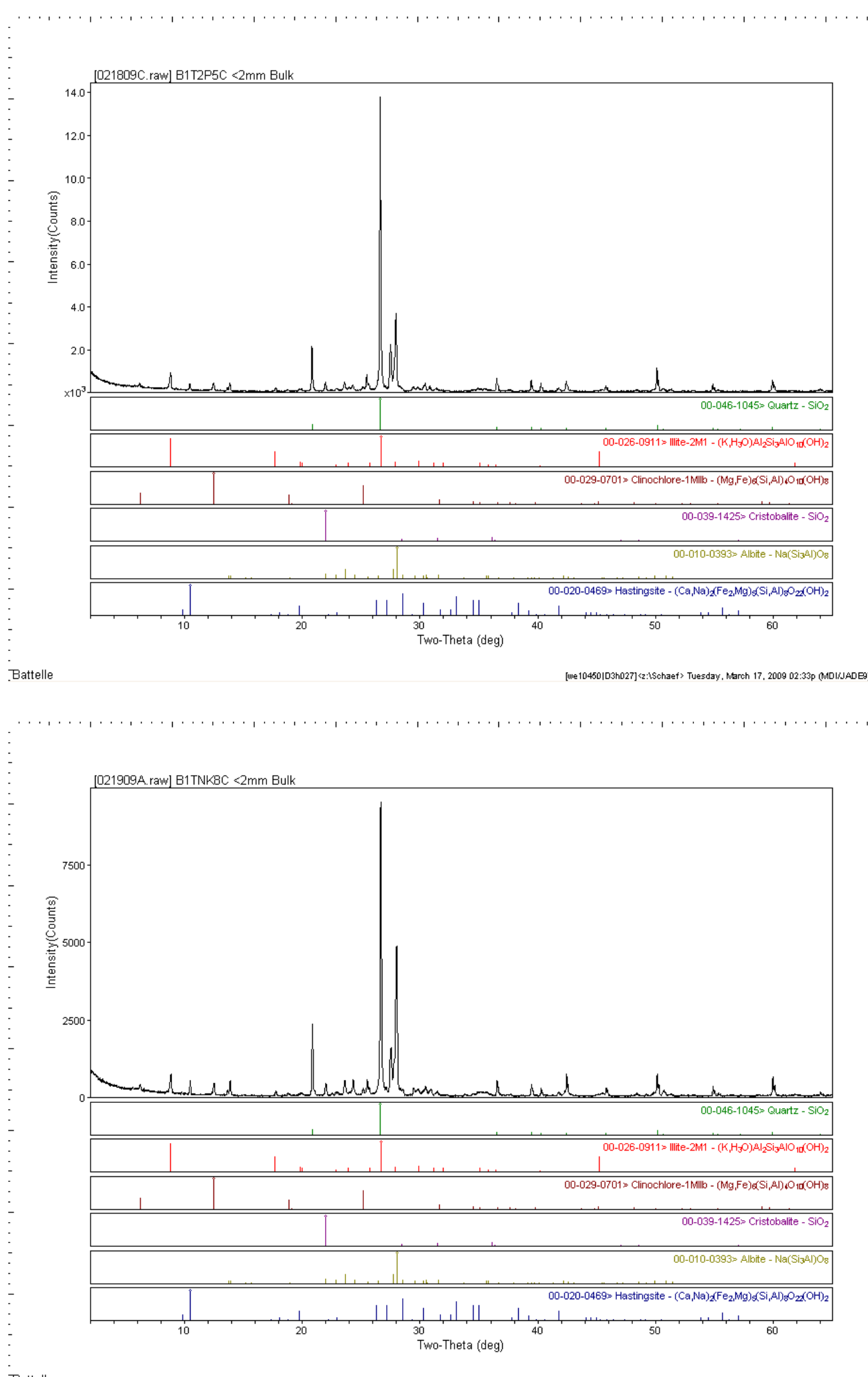

Battelle

[we 10450|[3h027]〈z:LSchaef> Tuesday, March 17, 2009 02:33p (MDI/JADE9) 


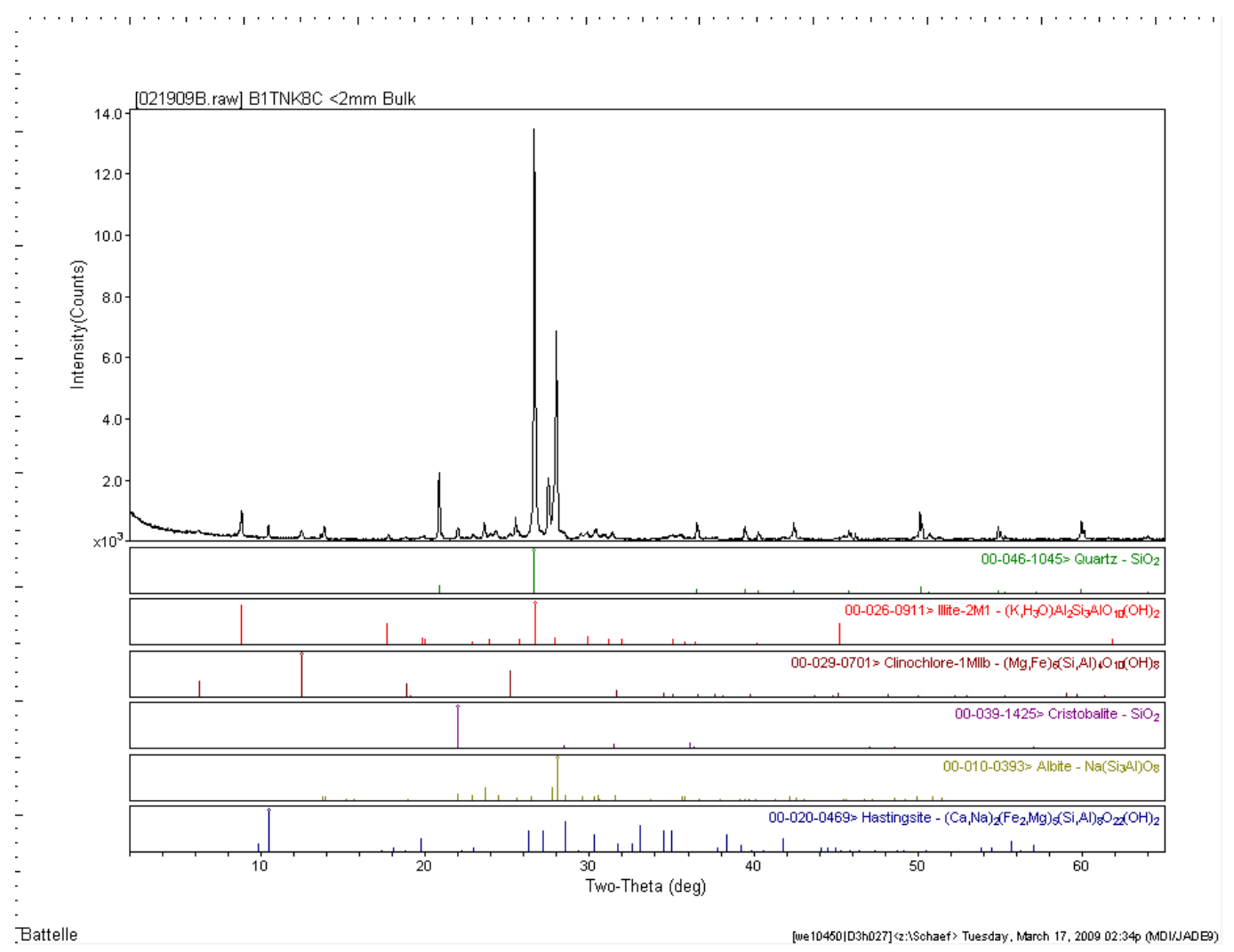




\subsection{Appendix B - Clay XRD Scans}

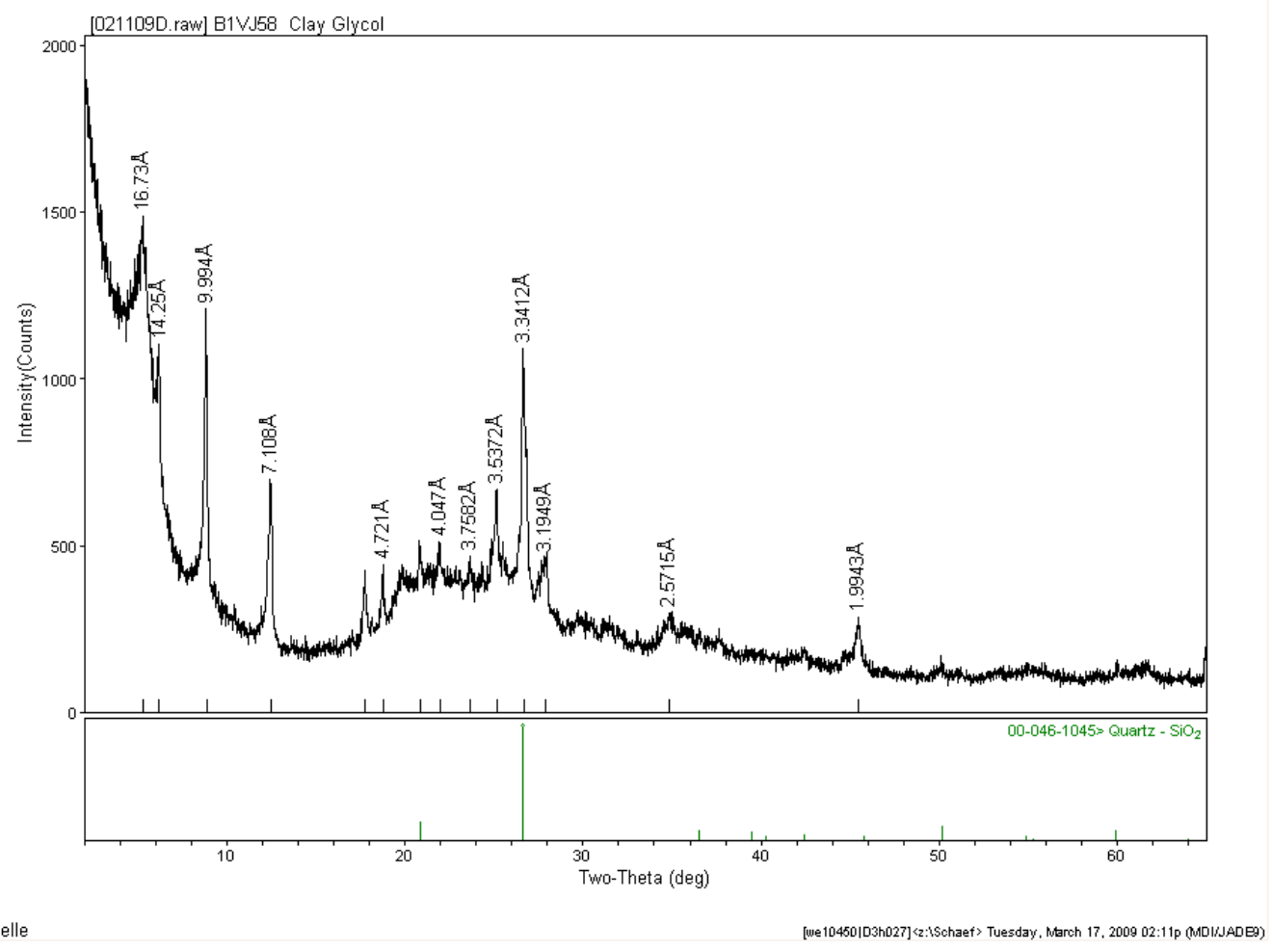




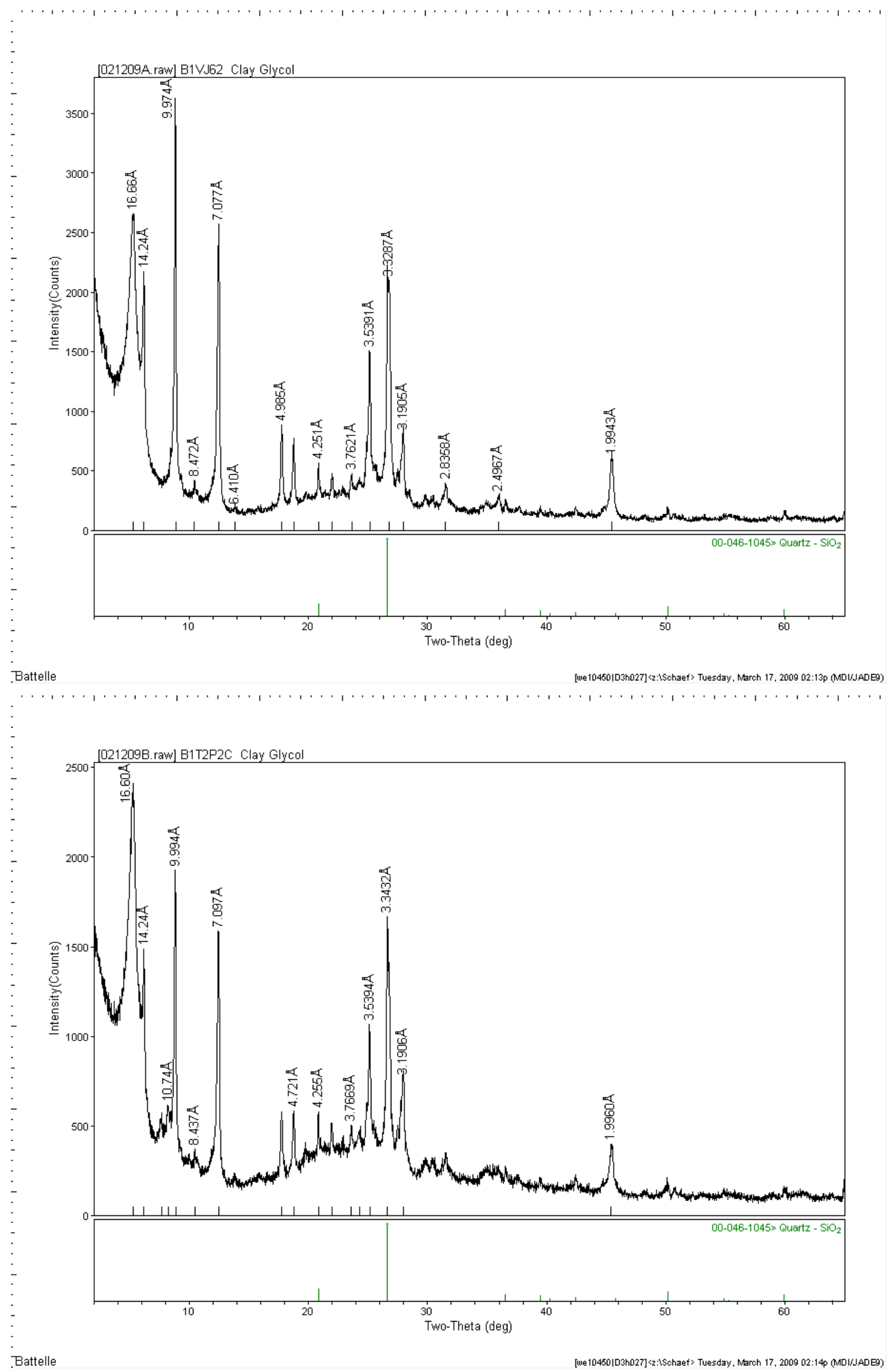



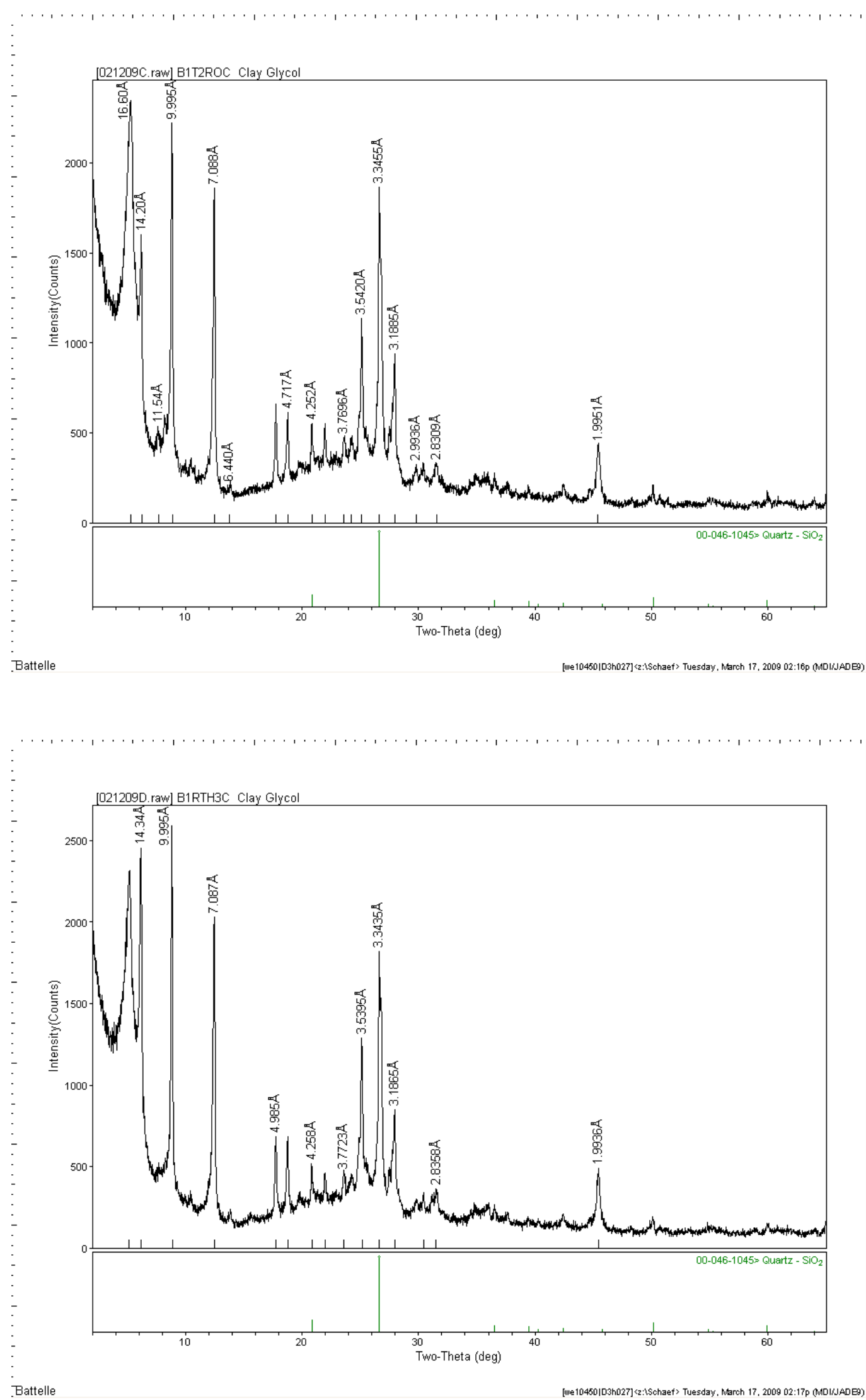

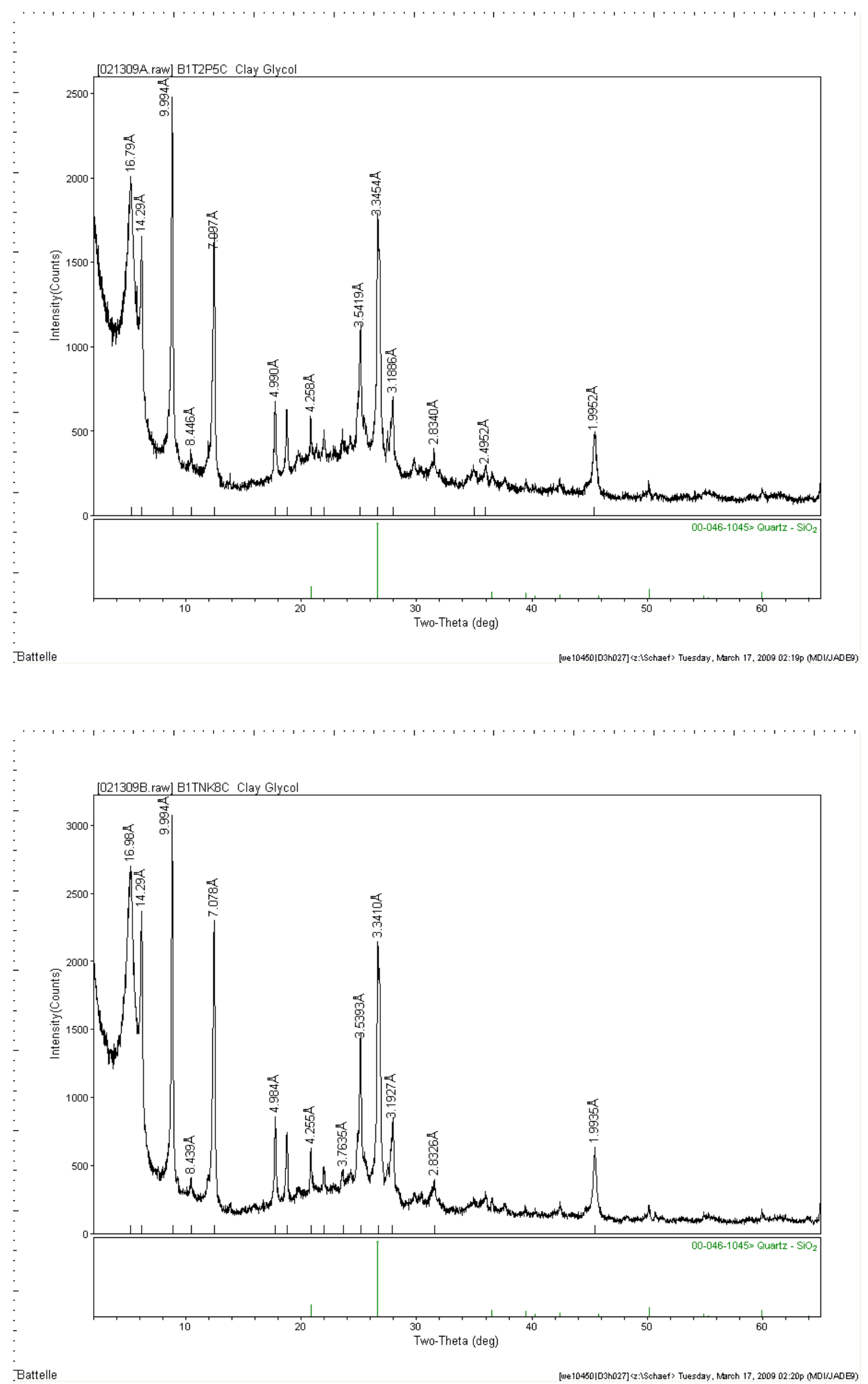


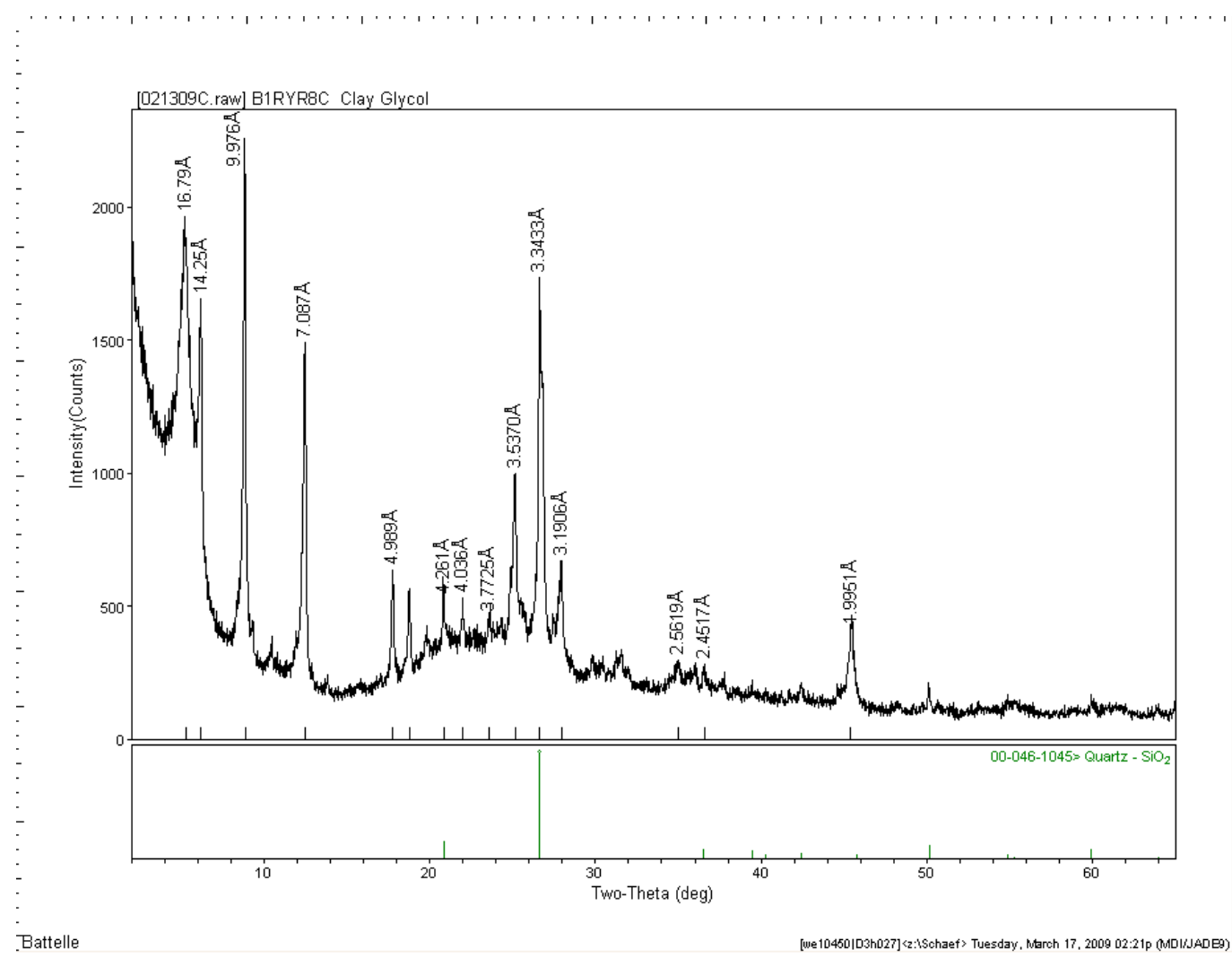




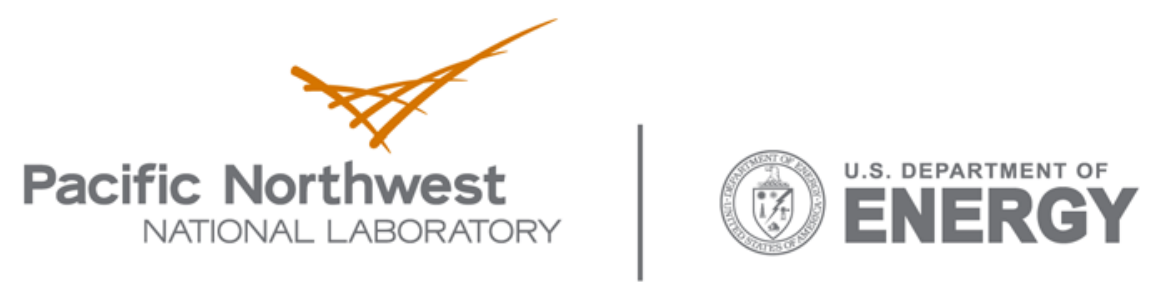

902 Battelle Boulevard

P.O. Box 999

Richland, WA 99352

1-888-375-PNNL (7665)

www.pnl.gov 